\title{
Cobalt and marine redox evolution
}

Elizabeth D. Swanner ${ }^{a, *}$, Noah J. Planavsky ${ }^{\mathrm{b}}$, Stefan V. Lalonde ${ }^{c}$, Leslie J. Robbins ${ }^{d}$, Andrey Bekker ${ }^{\mathrm{e}}$, Olivier J. Rouxel', Mak A. Saito ${ }^{g}$, Andreas Kappler ${ }^{\mathrm{a}}$, Stephen J. Mojzsis ${ }^{\mathrm{h}, \mathrm{i}, \mathrm{j}}$, Kurt O. Konhauser ${ }^{\mathrm{d}}$

\footnotetext{
a Eberhard-Karls University Tübingen, Sigwartstrasse 10, 72076 Tübingen, Germany

${ }^{b}$ Yale University, New Haven, CT 06520, USA

${ }^{c}$ European Institute for Marine Studies, Technopôle Brest-Iroise, 29280 Plouzané, France

d University of Alberta, Edmonton, Alberta, T6G 2E3, Canada

e University of Manitoba, Winnipeg, Manitoba, R3T 2N2, Canada

${ }^{\dagger}$ IFREMER, Centre de Brest, Technopôle Brest-Iroise, 29280 Plouzané, France

${ }^{g}$ Woods Hole Oceanographic Institution, Woods Hole, MA 02543, USA

h Ecole Normale Supérieure de Lyon and Université Claude Bernard Lyon 1, CNRS UMR 5276, 2 rue Raphaël Dubois, 69622 Villeurbanne, France

'Hungarian Academy of Sciences, Institute for Geological and Geochemical Research, 45 Budaörsi Street, H1112 Budapest, Hungary

j University of Colorado, UCB 399, 2200 Colorado Avenue, Boulder, CO 80309-0399, USA
}

\author{
*: Corresponding author : Elizabeth D. Swanner, tel.: +49 (0) 70712973061 ; \\ email address : elizabeth.swanner@ifg.uni-tuebingen.de
}

\begin{abstract}
:
Cobalt (Co) is a bio-essential trace element and limiting nutrient in some regions of the modern oceans. It has been proposed that Co was more abundant in poorly ventilated Precambrian oceans based on the greater utilization of $\mathrm{Co}$ by anaerobic microbes relative to plants and animals. However, there are few empirical or theoretical constraints on the history of seawater Co concentrations. Herein, we present a survey of authigenic Co in marine sediments (iron formations, authigenic pyrite and bulk euxinic shales) with the goal of tracking changes in the marine Co reservoir throughout Earth's history. We further provide an overview of the modern marine Co cycle, which we use as a platform to evaluate how changes in the redox state of Earth's surface were likely to have affected marine Co concentrations. Based on sedimentary Co contents and our understanding of marine Co sources and sinks, we propose that from ca. 2.8 to $1.8 \mathrm{Ga}$ the large volume of hydrothermal fluids circulating through abundant submarine ultramafic rocks along with a predominantly anoxic ocean with a low capacity for Co burial resulted in a large dissolved marine Co reservoir. We tentatively propose that there was a decrease in marine Co concentrations after ca. $1.8 \mathrm{Ga}$ resulting from waning hydrothermal Co sources and the expansion of sulfide Co burial flux. Changes in the Co reservoir due to deep-water ventilation in the Neoproterozoic, if they occurred, are not resolvable with the current dataset. Rather, Co enrichments in Phanerozoic euxinic shales deposited during ocean anoxic events (OAE) indicate Co mobilization from expanded anoxic sediments and enhanced hydrothermal sources. A new record of marine Co concentrations provides a platform from which we can reevaluate the role that environmental Co concentrations played in shaping biological Co utilization throughout Earth's history.
\end{abstract}

Highlights : Authigenic iron oxides and pyrite record marine Co concentrations. The Precambrian marine Co reservoir was greatest from 2.8-1.84 Ga. Sedimentary Co enhancements are linked to anoxia and hydrothermal activity. A Neoproterozoic drop in the marine Co reservoir with ventilation is not resolvable. The marine Co reservoir broadly corresponds to acquisition of Co-binding proteins.

Keywords: cobal ; trace element proxies ; ocean redox ; shale ; iron formation ; pyrite

Abbreviations : Co, cobalt ; Fe, iron ; Mn, manganese ; IF, iron formation ; OMZ, oxygen minimum zone ; OAE, oceanic anoxic event ; MAR, mass accumulation rate 


\section{1. Introduction}

65 The availability of bio-essential trace elements such as $\mathrm{Fe}, \mathrm{Mo}, \mathrm{Zn}, \mathrm{Co}, \mathrm{Ni}$, and $\mathrm{Cu}$ 66 underpins the emergence, long-term evolution, and activity of life on our planet. The

67 record of trace element utilization imprinted in modern organisms is commonly thought

68 to reflect metal availability in seawater when key metalloproteins evolved (Dupont et al.,

69 2006; Fraústo da Silva and Williams, 2001; Zerkle et al., 2005). The availability and

70 removal of trace elements within aqueous habitats for life reflects the compositional

71 evolution of the Earth's crust, but is also controlled by redox changes driven by

72 metabolic innovation (Anbar, 2008). Temporal patterns in the concentrations and

73 isotopic variations of trace elements in ancient sediments can serve as proxies for major

74 changes in redox conditions in the oceans and atmosphere over geologic timescales

75 (Anbar, 2008; Konhauser et al., 2009; Scott et al., 2008; Scott et al., 2012), and can

76 provide a means to test the idea that environmental availability controlled the

77 evolutionary history of metal utilization. However, empirical records of metal variation

78 through time have only been described for a few trace elements. For some elements

79 (e.g., Mo), the geochemical and biological records roughly converge on and support the

80 interpretation of limited availability and biological utilization for early organisms (David

81 and Alm, 2011; Scott et al., 2008). For other metals, the records do not match so well.

82 For instance, $\mathrm{Zn}$ is an especially important yet relatively late adoption in eukaryotic

83 metal-binding protein domains. As such, it was believed that $\mathrm{Zn}$ was relatively scarce in

84 seawater until the Neoproterozoic when the oceans became fully oxygenated (Dupont

85 et al., 2006). Yet, surprisingly, $\mathrm{Zn}$ abundance in the oceans appears to have been

86 relatively constant throughout much of Earth's history (Scott et al., 2012), and Zn 
87 bioavailability may have been limited by the formation of soluble complexes with

88 organics or sulfide (Robbins et al., 2013). Similarly, Ni concentrations were elevated in

89 Archean seawater (Kamber, 2010; Konhauser et al., 2009), yet the proteomic record

90 suggests increasing post-Archean biological Ni utilization (e.g. David and Alm, 2011).

91 Genomic reconstructions support the early biological utilization of Co (David and Alm,

92 2011; Dupont et al., 2006), perhaps reflecting an ancient abundance of dissolved

93 marine Co relative to the modern oceans. However, this model has not yet been tested

94 against the geological record.

95 Cobalt is a bio-essential metal for life, forming amongst others, the central cobalt-

96 corrin complex of cobalamin (vitamin $\mathrm{B}_{12}$ ). Eukaryotes use Co primarily as cobalamin in,

97 for example, methionine synthesis. Bacteria and archaea additionally use cobalamin in

98 enzymes for anaerobic metabolisms, including fermentation, dehalogenation, and one-

99 carbon compound electron transfers (Banerjee and Ragsdale, 2003). Direct binding of

100 Co also occurs in enzymes such as nitrile hydratase, used in amide metabolism. Cobalt

101 can also substitute for $\mathrm{Zn}$ in carbonic anhydrase, an enzyme responsible for

102 interconversion of $\mathrm{CO}_{2}$ and bicarbonate in some phytoplankton, suggesting that marine

103 Co availability is important in regulating the global carbon cycle (Morel et al., 1994).

104 Cobalt concentrations in modern seawater vary from 3 to 120 pM (Saito and Moffett, 105 2002), with variations dependent on interactions with other metals, biota and organic 106 matter. Cobalt shows nutrient-like behavior with surface minimum concentrations due to 107 biological uptake by phytoplankton (Saito et al., 2010; Saito and Moffett, 2002). Yet 108 strong Co ligands complex nearly all of the dissolved Co in some oligotrophic waters 109 (Noble et al., 2008; Saito, 2004; Saito and Moffett, 2001; Saito et al., 2005), although 
110 some portion of this complexed Co pool is likely bioavailable (Saito, 2004; Saito and

111 Moffett, 2001). In coastal and deep waters, Co behaves as a scavenged-type element

112 (Moffett and Ho, 1996; Saito, 2004), becoming oxidized and adsorbed to Mn(III,IV)

113 oxides as they precipitate (Murray and Dillard, 1979). Co scavenging is thought to be

114 catalyzed by Mn(II)-oxidizing bacteria (Moffett and Ho, 1996; Murray et al., 2007).

115 Previous estimates of marine Co concentrations through Earth's history were based

116 on thermodynamic considerations and assumptions regarding evolving marine redox

117 and chemical composition (Saito et al., 2003), and did not consider how some key

118 sources and sinks changed through time. Furthermore, equilibrium mineral precipitation

119 models neglect kinetic control over precipitation. In this study, we use the sedimentary

120 record of Co to track first-order changes in the marine Co reservoir through time, along

121 with estimated magnitudes of the modern sources and sinks to infer the causes for Co

122 reservoir change. We also suggest that the contents of Co of authigenic marine pyrite

123 can be used as a proxy for marine Co concentrations.

125 2. Behavior of Co in marine environments

126 The formation of authigenic marine phases is subject to thermodynamic control,

127 based on the abundance and speciation of ions, redox, and $\mathrm{pH}$ conditions. However,

128 kinetically-driven scavenging reactions also influence the composition of marine

129 precipitates. As a basis for the discussion below, Eh-pH diagrams detailing Co

130 speciation were generated with the Act2 module of Geochemists' Workbench using the

131 Minteq thermodynamic database from 2005. Cobalt(II) was set to $100 \mathrm{nM}, \mathrm{Fe}(\mathrm{II})$ and

$132 \mathrm{Mn}$ (II) to $50 \mu \mathrm{M}$, bicarbonate to $5 \mathrm{mM}$, silica to $2.2 \mathrm{mM}$ (saturation with amorphous 
133 silica; Konhauser et al., 2007) in seawater ionic strength; physical constraints were

$13425^{\circ} \mathrm{C}$ and 1 atmosphere ambient pressure. Cobalt does not form carbonate compounds, 135 and $\mathrm{Co}(\mathrm{OH})_{3}$ precipitates are only possible at very high Eh-pH conditions (Fig. 1).

136 Cobalt(II) is oxidized to $\mathrm{Co}(\mathrm{III})$ in the same Eh-pH space where Mn(II) oxidation occurs, 137 accounting for the oxidation of $\mathrm{Co}$ (II) and adsorption of $\mathrm{Co}$ (III) to precipitated $\mathrm{Mn}$ (III,IV) 138 oxides (Murray and Dillard, 1979; Takahashi et al., 2007). Iron(II) is oxidized to Fe(III) at 139 a lower redox potential than $\mathrm{Co}(\mathrm{II})$ and $\mathrm{Mn}(\mathrm{II})$ at marine $\mathrm{pH}(\sim 8)$.

140 Adsorption of $\mathrm{Co}$ (II) and $\mathrm{Co}$ (III) to surface sites on Fe(III) (oxyhydr)oxides (Musić et 141 al., 1979) and Mn(III,IV) oxides (Takahashi et al., 2007), respectively, is an important 142 pathway for scavenging of Co under oxic conditions (Koschinsky and Hein, 2003; 143 Stockdale et al., 2010; Takahashi et al., 2007). Soluble Co maxima occur below the $\mathrm{O}_{2^{-}}$

$144 \mathrm{H}_{2} \mathrm{~S}$ chemocline in modern euxinic basins in conjunction with both the soluble $\mathrm{Fe}$ and 145 Mn peaks (Dryssen and Kremling, 1990; Öztürk, 1995; Viollier et al., 1995), which 146 indicates that $\mathrm{Co}$ is released by reductive dissolution of both $\mathrm{Mn}(\mathrm{III}, \mathrm{IV})$ oxides and $147 \mathrm{Fe}(\mathrm{III})$ (oxyhydr)oxides. Both poorly crystalline and crystalline $\mathrm{Fe}(\mathrm{III})$ (oxyhydr)oxide 148 surfaces efficiently scavenge $\mathrm{Co}(\mathrm{II})$ in waters with $\mathrm{pH}$ above 7 (Borggaard, 1987; 149 Gunnarsson et al., 2000; Musić et al., 1979; Dzombak and Morel, 1990), likely as 150 bidentate inner-sphere complexes (Beak et al., 2011), while Co(III) is substituted for $\mathrm{Mn}$ 151 in $\mathrm{Mn}(\mathrm{III} / \mathrm{IV}$ ) oxides (Manceau et al., 1997). Correlation between Co and $\mathrm{Fe}$ in 152 hydrothermal sediments collected from Endeavor Segment, Juan de Fuca (Fig. 2; data 153 from Hrishceva and Scott, 2007) implies a common delivery path for both metals and is 154 consistent with an Fe(III) (oxyhydr)oxide Co shuttle.

155 Sorption of $\mathrm{Co}(\mathrm{II})$ to ferrihydrite, likely the dominant Co scavenging pathway in 
$156 \mathrm{Fe}$ (II)-rich seawater (e.g. Konhauser et al., 2009), was investigated with MINTEQ using

157 constants and site densities previously determined for ferrihydrite (Dzombak and Morel,

158 1990). Activities of dissolved components were corrected using the Davies equation,

159 and modeling utilized $100 \mathrm{pM}$ initial $\mathrm{Co}(\mathrm{II}), 0.56 \mathrm{M} \mathrm{NaCl}$ electrolyte to simulate seawater,

160 and $1 \mathrm{~g} / \mathrm{L}$ free ferrihydrite mineral (a constant concentration of surface sites during

161 steady-state production of ferrihydrite). We compared Co sorption with and without Co

162 ligands at modern (ca. 40 pM; Saito, 2004; Saito and Moffett, 2001) and high (400 pM)

163 concentrations to investigate whether Co ligands prevent sorption of Co(II) to surface

164 sites of ferrihydrite. The amount of $\mathrm{Co}$ (II) sorbed was unaffected at marine $\mathrm{pH}$ with 40

$165 \mathrm{pM}$ ligands, but Co(II) sorption to ferrihydrite was negligible when ligand concentrations

166 were 400 pM (Fig. 3). We note that this model utilizes data for ligands specific to Co(II),

167 but Co(III)-ligand complexes are likely extremely inert (Saito et al., 2005), and should

168 further decrease the pool of Co available for metal sorption. We also did not examine

169 the effects of inorganic species(e.g. Si), which can compete with metals for surface

170 binding sites on ferrihydrite (Konhauser et al., 2007; Konhauser et al., 2009). As

171 illustrated by those studies, the presence of Si should lower the amount of metal bound

172 for any given dissolved Co concentration.

173 In oligotrophic surface waters, Co concentrations are controlled by phytoplankton

174 uptake and binding to organic ligands (Saito and Moffett, 2001, 2002) rather than by the

175 scavenging reactions with $\mathrm{Mn}$ that occur in coastal and deep waters (Moffett and Ho,

176 1996). Cobalt concentrations in phytoplankton are similar to abundances of $\mathrm{Cd}$ and $\mathrm{Cu}$

177 and enriched by as much as $10 x$ over Mo (Ho et al., 2003). Organic material can also

178 sorb trace elements and transfer them to sediments (Broecker and Peng, 1982; 
179 Krauskopf, 1956), although this process is not as quantitatively significant for Co as it is

180 for other metals (e.g., Cd, Zn; Algeo and Maynard, 2004; Yee and Fein, 2003).

181 The formation of sulfide minerals governs the concentrations of $\mathrm{Co}$ in anoxic and

182 sulfidic waters. Cobalt sulfide is more soluble than sulfides of some other biologically

183 important elements (e.g. Cu, Zn; Saito et al., 2003), and dissolved Co concentrations

184 below the chemocline of sulfidic waters can exceed average ocean concentrations by

185 several orders of magnitude (Dryssen and Kremling, 1990; Viollier et al., 1995).

186 Previous calculations suggested that the formation of Co-sulfide should scavenge

187 dissolved Co from sulfidic waters (Dryssen and Kremling, 1990; Kremling, 1983), but

188 little evidence exists for this particulate Co phase (Saito et al., 2003). However, field

189 observations show that some Co remains dissolved in sulfidic waters, while less soluble

190 metals (e.g., Cu, Cd) are rapidly removed (Öztürk, 1995; Viollier et al., 1995). The

191 exchange of the bisulfide ion with water molecules hydrating dissolved Co(II) is slower

192 than with those hydrating $\mathrm{Fe}(\mathrm{II})$, likely contributing to the persistence of dissolved Co(II)

193 in sulfidic waters (Morse and Luther III, 1999). For most sulfidic marine systems, this

194 means that while FeS is more soluble than CoS (e.g. Saito et al., 2003), FeS formation

195 is kinetically favored, and Co is incorporated into FeS rather than precipitating as CoS

196 (Huerta-Diaz and Morse, 1992; Morse and Arakaki, 1993).

197 The concentration of metals, including Co, in sulfidic waters is also buffered by the 198 formation of soluble metal-sulfide complexes (Daskalakis and Helz, 1992), although this 199 seems to be more important for metals such as $\mathrm{Cd}, \mathrm{Zn}$, and $\mathrm{Cu}$ that form stronger 200 sulfide complexes. However, above $1 \mu \mathrm{M}$ total sulfide, soluble Co-sulfide complexes will 201 reduce the dissolved Co(II) pool (Saito et al., 2003). Regardless of the initial phase of 
202 aqueous precipitate, Co ultimately substitutes into pyrite during sedimentary diagenesis 203 (Huerta-Diaz and Morse, 1992; Stockdale et al., 2010).

204

\section{3. Marine Co sources and sinks}

206 The concentration of elements in seawater reflects a balance between delivery and

207 removal of elements via precipitation and adsorption processes (e.g. Broecker, 1971;

208 Krauskopf, 1956). To quantitatively interpret changes in the marine Co reservoir, as

209 recorded by sediments deposited under different redox conditions, we detail below

210 estimates of the fluxes of dissolved Co to seawater, and mass accumulation rates

211 (MAR) for sediments deposited under oxic, anoxic and euxinic conditions (Table 1).

213 3.1 Marine Co sources

214 The amount of Co present in the crust ultimately governs the amount of Co delivered 215 to the oceans through fluid-rock interaction. Minerals with higher $\mathrm{Fe}, \mathrm{Mg}$, and $\mathrm{Cr}$ 216 contents are also enriched in Co (Carr and Turekian, 1961), specifically olivine and 217 pyroxene present in ultramafic rocks (Glassley and Piper, 1978). Dissolved Co is 218 delivered to seawater via rivers and hydrothermal fluids that source Co predominantly 219 from mafic and ultramafic rocks. The estimated riverine flux of Co is $5.5 \times 10^{12} \mathrm{~g} \mathrm{kyr}^{-1}$ 220 (Table 1; Gaillardet et al., 2003). Cobalt fluxes from the continents were likely higher 221 prior to $2.5 \mathrm{Ga}$ due to their more mafic compositions, after which average Co 222 concentrations in the continental crust dropped from 22 to $15 \mathrm{ppm}$ (Condie, 1993). Dust 223 can add dissolved Co to surface waters, but this process is likely to be minor and 224 geographically and seasonally restricted (Shelley et al., 2012). 
225 Although recent work has highlighted the role of hydrothermal fluids in supplying 226 scavenged-type elements to the ocean reservoir (e.g. Fe; Saito et al., 2013; Tagliabue 227 et al., 2010), initial measurements have found little evidence for Co fluxes from 228 hydrothermal systems to seawater (Noble et al., 2012; Noble et al., 2008). However, 229 hydrothermal fluids contain Co in concentrations often several orders of magnitude 230 above average seawater (Metz and Trefry, 2000), implying that delivery of hydrothermal 231 Co to open oceans is limited by efficient, near-field scavenging reactions in oxic 232 seawater (German et al., 1991). Using the fluid flow volume through high- and low233 temperature hydrothermal systems as estimated from the oceanic $\mathrm{Mg}$ budget by 234 Elderfield and Schultz (1996), we calculated Co fluxes out of both types of systems as 235 described by Reinhard et al. (2013). The Co anomaly for high-temperature systems 236 utilized the difference between concentrations within the Plume vent on the Juan de 237 Fuca Ridge (200 $\mathrm{nmol} \mathrm{kg}{ }^{-1}$ at $\left.246^{\circ} \mathrm{C}\right)$ and bottom waters $\left(0.02 \mathrm{nmol} \mathrm{kg}{ }^{-1}\right.$; Metz and 238 Trefry, 2000). The Co anomaly for low-temperature systems was based on Co data 239 from site 1027 on the Juan de Fuca Ridge $\left(0.7 \mathrm{~nm} \mathrm{~kg}^{-1}\right.$ at $\left.64^{\circ} \mathrm{C}\right)$ relative to bottom 240 waters $\left(0.03 \mathrm{nmol} \mathrm{kg}{ }^{-1}\right.$; Wheat et al., 2003). We estimate a total hydrothermal Co flux of

$2411.2 \times 10^{11} \mathrm{~g} \mathrm{Co} \mathrm{kyr}^{-1} ; 2.4 \%$ of total the total Co flux (Table 1). We recognize that the net 242 fluxes of most hydrothermally derived metals to the open ocean remain poorly 243 constrained; metals released from hydrothermal vents are readily incorporated into 244 sulfide or oxide precipitates within plumes, thereby diminishing dispersion. However, 245 nanoparticulate sulfides or organic ligands may stabilize and transport trace elements 246 away from vents (Sander and Koschinsky, 2011; Toner et al., 2009; Yucel et al., 2011), 247 increasing trace element, and probably Co, fluxes to the global ocean. We therefore 
248 anticipate that global fluxes of Co from hydrothermal systems will be refined in the near

249 future (e.g. GEOTRACES).

$251 \quad 3.2$ Oxic sedimentary Co sinks

252 In sediments where oxygen penetrates at least $1 \mathrm{~cm}$, authigenic $\mathrm{Fe}(\mathrm{III})$ 253 (oxyhydr)oxides, Mn(III/IV) oxides and associated Co are permanently buried 254 (Brumsack, 1989; Froelich et al., 1979). Any $\mathrm{Fe}(\mathrm{II})$ and $\mathrm{Mn}(\mathrm{II})$ released during 255 dissimilatory microbial reduction is reoxidized and immobilized before diffusing out of 256 sediments. Deposition of phytoplankton biomass may also add Co to oxic sediments 257 (Saito, 2004). Regardless of the pathway for authigenic Co delivery to sediments, Co 258 released during early diagenesis is immobilized by scavenging with $\mathrm{Fe}(\mathrm{III})$ 259 (oxyhydr)oxides and Mn(III/IV) oxides. Cobalt fluxes to oxic continental margin and 260 hydrothermal sediments are likely higher than those in the deep sea (Douglas and 261 Adeney, 2000; Koschinsky and Hein, 2003), but these fluxes are not well-constrained. 262 Therefore, we use an estimate of 2.3-5 $\mu \mathrm{g} \mathrm{Co} \mathrm{cm}^{-3} \mathrm{kyr}^{-1}$ (Krishnaswami, 1976) from 263 deep-sea pelagic sediments for an average authigenic oxic Co MAR.

\section{3.3 Euxinic sedimentary Co sinks}

266 Modern sulfidic (sulfide in porewaters) or euxinic (sulfide in bottom waters) 267 environments include basins where authigenic $\mathrm{Fe}(\mathrm{III})$ (oxyhydr)oxides and $\mathrm{Mn}$ (III/IV) 268 oxides are reductively dissolved below the $\mathrm{O}_{2}-\mathrm{H}_{2} \mathrm{~S}$ transition zone, releasing associated 269 Co (Dryssen and Kremling, 1990; Öztürk, 1995; Viollier et al., 1995). To estimate an 
270 euxinic Co MAR, we subtracted the average terrigenous Co/Al ratio $\left(198 \mu \mathrm{g} \mathrm{g}^{-1}\right)$ from

271 the Co/Al ratio of euxinic sediments (204 $\mathrm{gg} \mathrm{g}^{-1}$; within errors) from the perennially

272 euxinic Cariaco basin near Venezuela (Piper and Dean, 2002). Utilizing an average

273 sedimentation rate, density, and porosity for euxinic Cariaco sediments (Lyons et al.,

274 2003), our estimated euxinic Co MAR is $5 \mu \mathrm{g} \mathrm{Co} \mathrm{cm}^{-3} \mathrm{kyr}^{-1}$ (Table 1). We acknowledge

275 that there are large errors in this estimate, and higher euxinic Co MAR are observed in

276 restricted basins (Brumsack, 1989; Hetzel et al., 2009). Although Co is likely enriched

277 above detrital levels in euxinic sediments, there is almost an order of magnitude lower

278 enrichment than metals that form strong sulfide complexes (e.g., Mo), which can be

279 enriched up to $100 x$ above concentrations in oxic sediments (Algeo and Maynard,

280 2004). Cobalt MAR in euxinic sediments below open marine conditions (5 $\mu \mathrm{g} \mathrm{Co} \mathrm{cm}^{-3}$

$281 \mathrm{kyr}^{-1}$ ) are similar to Co MAR in oxic marine sediments $\left(2.3\right.$ to $5 \mu \mathrm{g} \mathrm{Co} \mathrm{cm}^{-3} \mathrm{kyr}^{-1}$ ), in

282 contrast to Mo (see Scott et al., 2008), demonstrating that expansion of euxinic

283 sediments at the expense of oxic sediments, or vice versa, should not result in major

284 changes to the Co reservoir.

285

286 3.4 Anoxic sedimentary Co sinks

287 In anoxic marine sediments lacking dissolved sulfide, Fe(III) (oxyhydr)oxides and $288 \mathrm{Mn}(\mathrm{III} / \mathrm{IV})$ oxides are subject to dissimilatory microbial reduction. Fluxes of $\mathrm{Co}(\mathrm{II})$ and $289 \mathrm{Mn}(\mathrm{II})$ have been observed out of sediments underlying oxygen- and sulfide-poor 290 bottom water (Brumsack, 1989; Saito, 2004), and plumes of dissolved Co mobilized 291 from anoxic sediments have been observed over oxygen minimum zones (OMZs; Noble 292 et al., 2012), demonstrating the mobility of Co under anoxic conditions. While 
293 remobilization under anoxic conditions is an important source of Co in some coastal

294 environment, this process does not represent an exogenous supply of Co, and so we

295 have not included reducing sediments as a source in flux estimates. Because Co is

296 readily mobilized from anoxic sediments, there is no significant flux of Co to anoxic

297 sediments, and Co in anoxic sediments solely reflects what is added with detrital

298 minerals (Brumsack, 1989; van der Weijden et al., 2006). Thus, a decrease in the extent

299 of anoxic sediments at the expense of oxic or euxinic sediments will decrease the size

300 of dissolved Co reservoir, while expansion of anoxic sediments should increase the size

301 of the reservoir.

302 Generally speaking, sediments deposited under an anoxic but non-sulfidic water

303 column, which are often referred to as ferruginous sediments, are also unlikely to

304 permanently remove Co. Rare in the modern but common in the Precambrian,

305 ferruginous sediments are characterized by overlying water column with anoxic

306 conditions with $\mathrm{Fe}(\mathrm{II})$ as the main redox buffer (Planavsky et al., 2011). These redox

307 conditions also allowed for the deposition of iron formations (IF), which are likely to be a

308 significant Co sink (Fig. 4). However, IFs reflect stabilization of $\mathrm{Fe}(\mathrm{III})$ (oxyhydr)oxides

309 under anoxic conditions where there was anomalously high local $\mathrm{Fe}(\mathrm{III})$ fluxes.

310 Furthermore, most oxide facies IF are found in deep water settings, and oxides are

311 preserved due to a lack of sufficient organic carbon to drive complete $\mathrm{Fe}$ (III) reduction

312 (Konhauser et al., 2005). Therefore, IF likely have higher capacities for Co burial (with

313 authigenic $\mathrm{Fe}$ (III) (oxyhydr)oxides) than modern anoxic sediments, although IFs

314 represent a small fraction of overall marine ferruginous settings. 


\section{Archives of Marine Co concentrations}

317 We propose that sedimentary Co concentrations can serve as an archive of marine

318 Co concentrations. We use this premise to evaluate how key sources and sinks for Co

319 have varied through time. This compilation also informs the evolution of marine redox

320 conditions. We focus on two types of sedimentary archives: those in which Co was

321 sequestered by authigenic Fe(III) (oxyhydr)oxides (IF database), or by iron sulfides

322 (sedimentary pyrite and euxinic shale databases).

3244.1 Iron formations as a Co archive

Iron(III) (oxyhydr)oxides, generally thought to be the precursor phases to most IF,

327 have extremely large and reactive surfaces that extensively adsorb cations, including $328 \mathrm{Co}(\mathrm{II})$, at marine $\mathrm{pH}$ (Dzombak and Morel, 1990). Therefore, we propose that the record 329 of authigenic Co enrichment in IF can be used to evaluate large-scale changes in 330 marine Co concentrations through time. Similar chemical principles justified using Ni, P, $331 \mathrm{Cr}$ and $\mathrm{Zn}$ enrichments in IF to track changes in seawater concentrations of these 332 elements (Konhauser et al., 2011; Konhauser et al., 2009; Planavsky et al., 2010b; 333 Robbins et al., 2013). Precambrian IF are chemical precipitates with minor detrital input. 334 Authigenic, but diagentically and metamorphically altered, Fe-rich (hematite, magnetite, 335 siderite) and Si-rich (quartz) phases dominate the mineralogy of IF, and so their trace 336 element composition is often inferred to reflect input of these elements from authigenic 337 vs. detrital phases. Post-depositional alteration of the primary trace element seawater 338 signatures is generally minimal unless IF have experienced hydrothermal alteration or 339 near surface weathering (Bau and Moeller, 1993). 
340 Historically, Precambrian IF are divided into Algoma-type, which have a spatially

341 limited extent and formed in proximity to volcanic and hydrothermal settings, and

342 Superior-type, which are more extensive and where deposited under marine conditions

343 on a continental shelf or an isolated basin. Both deposits are represented in our dataset

344 and we assign each IF as being Algoma- or Superior-type for simplicity; in reality there

345 is a gradation between these IF types (see Bekker et al., 2010). Large, basin-scale IF

346 deposition experienced a hiatus in the Middle Proterozoic, and a return to IF deposition

347 in the Neoproterozoic was followed by permanent cessation of IF deposition. The lack of

348 IF in intervening intervals is evident in our compilation. We further utilize exhalite

349 deposits and oolitic ironstones to extend the record of Co burial with authigenic Fe oxide

350 facies into the Phanerozoic.

351 We utilize an expanded dataset of Konhauser et al. (2011; 2009), comprising

352 published values as well as new data acquired by bulk analysis and in situ LA-ICP-MS.

353 Supplementary Table 1 reports $\mathrm{Co}, \mathrm{Al}, \mathrm{Ti}, \mathrm{Fe}, \mathrm{Mn}$, and $\mathrm{S}$ concentrations (where

354 available) for the 1353 Co data points used in this study. The supplementary information

355 also includes references for the published data and the descriptions of iron formations

356 analyzed in this study.

$358 \quad 4.2$ Pyrite as a Co archive

359 The partitioning of Co into iron sulfide phases is dependent on Co and $\mathrm{Fe}$ 360 concentrations, but importantly for our purposes, it appears to be largely independent of 361 the amount of hydrogen sulfide (Morse and Arakaki, 1993). In most sulfidic 362 environments, dissolved $\mathrm{Fe}^{2+}$ concentrations are near levels predicted from equilibrium 
363 with the amorphous Fe-S phase mackinawite (e.g. Helz et al., 2011). Finally, silicate 364 phases react with sulfide $10^{8} \mathrm{X}$ more slowly than $\mathrm{Fe}(\mathrm{III})$ (oxyhydr)oxide minerals 365 (Canfield et al., 1992), so Co in detrital minerals should not contribute to Co 366 concentrations in pyrite. Therefore, it is reasonable to assume that the degree of 367 authigenic Co enrichment in sediments deposited below euxinic waters should, to a first 368 order, reflect the dissolved Co concentrations in the water column.

369 In order to use trace element concentrations within pyrite as proxies for seawater 370 concentrations during sediment deposition, it is essential that (1) pyrites formed within

371 the sediments that host them, and (2) the metal inventory of pyrite was not overprinted

372 by secondary alteration processes. In the absence of free oxygen in the Archean 373 atmosphere, detrital pyrite was delivered to marine sediments (Rasmussen and Buick, 374 1999). Therefore, only sulfides with early diagenetic textures (e.g. nodules or 375 disseminated grains) From shales with abundant organic carbon and sulfur and were 376 included in this study (Rouxel et al., 2005), although not all of the sediments included in 377 this study have been definitively demonstrated to have been deposited under euxinic 378 conditions. Post-depositional disturbances to metal content were screened by selecting 379 samples with no obvious sign of alteration (Rouxel et al., 2005; Rouxel et al., 2006)

380 Individual pyrite grains from black shales were digested and trace element data were 381 acquired by Thermo Element2 HR-ICP-MS at Woods Hole Oceanographic Institution as 382 described by Rouxel et al. (2005). A basic description of each sample, as well as the 383 geological setting and age constrains for the host rock, are reported by Rouxel et al. 384 (2005). Previously unreported samples include Devonian-age black shales from the 385 Illinois basin, pyrite nodules from the ca. 1.8 Ga Gunflint Formation of Kakabeca Falls in 
386 Ontario, Canada, and pyrite from the ca. 2.7 Ga Manjeri Formation of the Belingwe Belt,

387 Zimbabwe. Cobalt concentrations are reported in Supplementary Table 2. Trace

388 element compositions of pyrite from modern anoxic sediments are taken from Huerta-

389 Diaz and Morse (1992) and reference cited therein.

390

$391 \quad 4.3 \quad$ Bulk euxinic shales as a Co archive

392 Cobalt is enriched in sediments deposited under euxinic conditions (Algeo and 393 Maynard, 2004), and the shales used in this study have Mo contents $>25 \mathrm{ppm}$, 394 consistent with euxinia (Scott and Lyons, 2012). Authigenic Co was distinguished from 395 detrital Co via normalization to a conservative element, in this case Al. This approach is 396 justified as the Co/Al ratio of fine-grained material derived from continents has varied 397 little through time (Condie, 1993), and is similar amongst several compilations (Condie, 398 1993; Kamber et al., 2005; Wedephol, 1971). The Co and Al values for euxinic 399 sediments used in this study have all been previously published (see Supplementary 400 references). Because it is not always straightforward to distinguish detrital from 401 authigenic trace elements in shales (e.g. Van der Weijden, 2002), we emphasize that 402 the IF and pyrite datasets are likely to be the most robust indicators of the marine 403 reservoir.

404

405

4.4 Statistical analysis of Co datasets

406 When grouped by ages that correspond to global events (described below), Co 407 concentrations were log-normally distributed. The statistical differences between 408 average time-binned values were compared using an unpaired t-test of log 
409 concentration values. The $p$ values for these comparisons are reported in Table 2. The

410 mean and one standard deviation (SD) of log concentration values were then back-

411 transformed to concentration values, and these are reported as mean $\left(\mu \mathrm{g} \mathrm{g}^{-1}\right) \cdot / \mathrm{SD}$ in

412 accordance with the multiplicative nature of a log-normal distribution (Limpert et al., 413 2001).

\section{5. Evolution of the marine Co reservoir}

4165.1 Reconstructing changes in Co sources and sinks through Earth history

417 The datasets of Co in IF, pyrite and shale reveal time-resolved patterns in the 418 delivery of Co to marine sediments, and thereby indicate first-order changes to the 419 marine Co reservoir through time (Fig. 4). The average Co/Ti $\left(\mu \mathrm{g} \mathrm{g}^{-1}\right)$ of IF $\geq 2.80 \mathrm{Ga}$ $420(79.85 \cdot 1.72)$ are significantly lower than IF deposited between 2.75 to $1.88 \mathrm{Ga}(150.57$ 421 / 2.67). Average values then significantly drop in IF, exhalite, and oolitic ironstones 422 deposited between $1.72 \mathrm{Ga}$ and modern times (62.25 / 1.84; Table 2), despite that 423 exhalites are prime records of locally derived hydrothermal Co. There is also a 424 significant difference between the average concentrations of Co (ppm) in pyrites from 425 shales deposited between 2.8 and $1.84 \mathrm{Ga}(7.34 \cdot / 1.77)$ and those deposited from 1.8 426 to $0.3 \mathrm{Ga}(3.87 \cdot / 1.96$; Table 2$)$, signifying a concordance of the IF and shale pyrite Co 427 records, and likely global-scale trends in marine Co concentrations.

428 Higher seawater Co concentrations in the interval between 2.8 and 1.84 Ga reflect 429 pervasive anoxia and a higher hydrothermal Co flux to the marine reservoir during the 430 emplacement of oceanic crust, likely due in part to several mantle plume events at this 
431 time (Barley et al., 2005; Rasmussen et al., 2012). These events also likely supplied the

432 Fe for major IF deposited from 2.5 to $2.4 \mathrm{Ga}$, and again between 2.0 and $1.8 \mathrm{Ga}$ (Barley

433 et al., 1997; Rasmussen et al., 2012). In hydrothermal systems, the supply of Co tracks

434 that of $\mathrm{Fe}$ (Douville et al., 2002) because the solubility of both elements is enhanced at

435 higher temperature and $\mathrm{Cl}^{-}$concentrations (Metz and Trefry, 2000). Archean-aged

436 hydrothermal systems are thought to have experienced higher heat flow, enhancing the

437 supply of Fe (Isley, 1995), and likely Co to seawater. Higher Co concentrations from

438 Archean hydrothermal fluids are also more likely due to the prevalence of ultramafic

439 oceanic crust (Arndt, 1983). Compositional control on Co concentrations in

440 hydrothermal fluids is indicated in the ultramafic Rainbow vent field on the Mid-Atlantic

441 Ridge, where Co concentrations reach up to $13 \mu \mathrm{M}$ Co (Douville et al., 2002), an

442 enrichment of at least $10^{5}$ above seawater concentrations. Persistent anoxia would

443 have allowed the dispersion of dissolved Co plumes without trapping near source by

444 oxidative scavenging (Noble et al., 2012). These factors indicate an increased

445 proportion of hydrothermal Co fluxes relative to continental Co fluxes in comparison to 446 modern Co inputs (Table 1).

447 The Co concentrations in younger than $1.84 \mathrm{Ga}$ IF are comparable to those prior to $4482.8 \mathrm{Ga}$ (Table 2), potentially indicating that weathering of mafic to ultramafic

449 Neoarchean continental crust is not an essential aspect of the large enrichments. This is 450 in contrast to $\mathrm{Ni}$, whose supply to oceans from weathering of emergent oceanic 451 plateaus waned after 2.7-2.6 Ga (Kamber, 2010; Konhauser et al., 2009). Although Co 452 and $\mathrm{Ni}$ have generally similar low-temperature geochemical behavior, they are 453 decoupled during high-temperature hydrothermal alteration. Nickel is not as efficiently 
454 leached as Co, resulting in low hydrothermal Ni fluxes (Douville et al., 2002).

455 Furthermore, Co-chloride complexes are more stable than $\mathrm{Cu}$-, and, probably, Ni456 chloride complexes, resulting in higher Co solubility at low temperatures (Metz and 457 Trefry, 2000). The increase in marine sediment Co concentrations after ca. 2.8 Ga may 458 be driven by changes in the riverine flux of Co from the continents due to increased, 459 permanent, subaerial exposure. Other authors have suggested the emergence of 460 continents between 2.9 and $2.7 \mathrm{Ga}$ (e.g. Pons et al., 2013 and references within).

461 However, the crustal growth rate slows and Co concentrations drop at $2.5 \mathrm{Ga}$, from 22$46225 \mathrm{ppm}$ to $15 \mathrm{ppm}$ (Condie, 1993), in the midst of the highest sedimentary Co 463 concentrations (Fig. 4 and 5).

464 We propose that the drop in Co concentrations in marine sediments that occurs after $4651.84 \mathrm{Ga}$, and reflects a cessation of hydrothermal activity and the emplacement of large 466 igneous provinces (Rasmussen et al., 2012). As supply of hydrothermal Fe and 467 deposition of massive IF waned in the late Paleoproterozoic, so too did the 468 hydrothermal Co flux, shifting towards modern conditions in which continentally-derived 469 Co dominates Co influx (Table 1). Hydrothermal supply to the oceans reached modern 470 levels by $0.7-0.8 \mathrm{Ga}$ (Derry and Jacobsen, 1988), with episodic larger mantle inputs re471 occurring throughout the Proterozoic and Phanerozoic (Peng et al., 2011; Veizer et al., 472 1983). Additional Middle Proterozoic samples would be needed to test whether later 473 mantle plume events resulted in a return to globally high marine Co concentrations.

474 The drop in seawater Co concentrations after $1.88 \mathrm{Ga}$ occurs at a time when the 475 extent of euxinic environments in the oceans increased (Poulton et al., 2004) at the 476 expense of ferruginous sediments. Without well-constrained depositional rates for IF, it 
477 is impossible to estimate Co MAR from ferruginous settings, although our IF dataset

478 attests to the fact that $\mathrm{Co}$ is effectively buried under ferruginous conditions.

479 Nevertheless, given that IFs are rare marine sediments, the contribution of ferruginous

480 sediments to overall Co removal in the oceans was likely low. Further, as stressed

481 above, the Co sink associated with ferruginous settings will be lower than for oxic

482 sediments; although $\mathrm{Fe}$ (III) (oxyhydr)oxides sorb $\mathrm{Co}, \mathrm{Mn}$ (III/IV) oxides, which form at

483 higher Eh, are much more effective at scavenging Co from seawater (Stockdale et al.,

484 2010). Therefore, expansion of euxinic settings to less than $10 \%$ of seafloor area in the

485 Middle Proterozoic (Reinhard et al., 2013), are unlikely to explain the drop in the Co

486 reservoir size (cf. Saito et al., 2003) without invoking a waning hydrothermal Co source.

487 Significant areal expansion of oxic and euxinic sediments might explain the drop in the

488 Co reservoir, but oxic conditions suitable for Co scavenging were likely confined to

489 Middle Proterozoic surface waters (Planavsky et al., 2010a), and sediments deposited 490 under oxic conditions were of limited extent (Reinhard et al., 2013).

491 The logarithmic range of Co concentrations in sediments, even those from the same 492 formation, is a phenomenon that has been observed for other trace elements (e.g. Zn; 493 Robbins et al., 2013; Scott et al., 2012). This variability is likely primary, based on 494 similar phenomena in modern authigenic sediments (Fig. 2 and 4). For Co, this may 495 reflect temporal variability in marine Co concentrations, which is expected because Co 496 is a non-conservative element within the oceans and has an extremely short residence 497 time in seawater, 280 years by our estimate (Table 1; 40-120 years; Saito and Moffett, 498 2002). Due to its short residence time, marine Co concentrations respond quickly to 499 perturbations in sources or sinks, such as the development of OMZ that fluctuate on 
500 decadal time scales (Noble et al., 2012; Stramma et al., 2008). The highest IF Co/Ti

501 (nearly $160,000 \mu \mathrm{g} \mathrm{g}^{-1}$ ) and pyrite Co (nearly $2000 \mathrm{ppm}$ ) are found in the $2.32 \mathrm{Ga}$

502 Timeball Hill Formation and the underlying Rooihoogte formations. Post-depositional

503 hydrothermal overprint is not likely responsible for elevated Co concentrations because

504 they do not correspond to high $\mathrm{Pb}$ or $\mathrm{Cu}$, concentrations (data not shown), which would

505 suggest mineralization. Some of this variation may be primary, and representative of

506 temporally or spatially variable Co concentrations within the basin. However, some

507 variability could be tied to re-distribution between Fe-phases during diagenesis. Despite

508 these variations, the robust statistical differences in time-binned averages (Table 2)

509 validate that shifts in sedimentary Co map onto global events, and hence, indicate

510 reservoir changes.

511 Although there are no significant changes in the average Co concentrations from

512 Middle Proterozoic to Phanerozoic in any of the sedimentary records (Table 2), there is

513 significant variability in Phanerozoic euxinic shales (Fig. 5), many of which were

514 deposited during ocean anoxic events (OAE), which reflect transient rather than

515 pervasive anoxic conditions. The average Co/Al ratios from euxinic black shales

516 deposited during the Cretaceous OAE-2A at Demerera Rise are $~ 2 X$ larger than euxinic

517 sediments deposited before or after (their Fig. 9; Hetzel et al., 2009). This is

518 dramatically different from other redox-sensitive metals such as Mo and $V$, whose

519 restricted supply was exhausted during the OAE, leading to depletions of Mo and $\mathrm{V}$

520 during the peak of the OAE relative to sediments deposited before and after. Cobalt is

521 mobilized from anoxic sediments (Noble et al., 2012), and therefore increased Co burial

522 in euxinic sediments might reflect this greater reservoir during anoxic events, and in fact 
523 be a proxy for low-oxygen conditions (Saito et al., 2010). OAE Co enrichments may also

524 be linked to, or augmented by a hydrothermal Co pulse (e.g. Brumsack, 2006).

525 Importantly, there is independent evidence for increased hydrothermal input from a 526 sharp shift toward less radiogenic (hydrothermally-derived) initial Os isotope values 527 during the onset of the OAE (Turgeon and Creaser, 2008). Furthermore, other authors 528 have also documented sedimentary Co increases during OAE intervals linked to 529 hydrothermal activity (Orth et al., 1993; Snow et al., 2005). Therefore, the OAE Co 530 records are consistent with the notions developed above that anoxia and hydrothermal 531 activity play a critical role in the global marine Co cycle, and that marine Co 532 concentrations respond on shorter timescales than conservative elements such as Mo.

533 Surprisingly, we find little evidence for a change in the marine Co reservoir with the 534 deep ocean oxygenation, potentially beginning as early as $635 \mathrm{Ma}$ (Sahoo et al., 2012). 535 The average Co/Al $\left(\mu \mathrm{g} \mathrm{g}^{-1}\right)$ for Proterozoic euxinic shales $(11.51 / 1.73)$ is not 536 significantly different from Phanerozoic-aged shales (9.33 / 1.97), although we 537 emphasize that Phanerozoic shales are dominated by OAE samples, and likely reflect 538 transient anoxia. There is also no statistical support for changes in IF or shale pyrite Co 539 concentrations during similar time intervals (data not shown). We note however, that a 540 paucity of datapoints from the Middle Proterozoic for all three databases hinders 541 interpretation of changes to the Co reservoir with deep ocean oxygenation. The highest 542 Phanerozoic Co concentrations occur in exhalites, which demonstrate that near-source 543 scavenging reactions prevent hydrothermal Co dispersal under oxic conditions, and 544 therefore Phanerozoic exhalites likely reflect only local Co concentrations. Non-OAE 545 euxinic shale pyrites would likely best track changes in the Co reservoir associated with 
546 ocean oxygenation. Because expanding oxic sediments at the expense of anoxic should

547 enhance Co removal, and Neoproterozoic hydrothermal activity is likely similar to

548 modern (Derry and Jacobsen, 1988), ocean ventilation should have further decreased

549 the Co reservoir size.

550

$551 \quad 5.3$ Marine Cobalt reservoir size and biological evolution

552 Our empirical record of the marine Co reservoir affords an opportunity to discuss

553 hypotheses of Co utilization in biology, and to consider how Co-utilization in aquatic

554 organisms fit to these hypotheses. The biological utilization of metalloproteins may

555 reflect the availability of elements in the environment in which the protein first appeared

556 (e.g. Nisbet and Fowler, 1996). Genomic analyses of all three domains of life indicate

557 that Co-binding proteins originated after 3.3 Ga (David and Alm, 2011). Given the

558 uncertainties in this age stated by the authors (>250 My), it is feasible that origin of

559 many Co-binding proteins coincides with the enhanced marine Co availability we

560 observe after $2.8 \mathrm{Ga}$, generally supporting the availability hypothesis. However, Co is

561 chemically suited to catalyze reactions involving hydrogen rather than oxygen (Fraústo

562 da Silva and Williams, 2001), and any preferential Co utilization by early organisms may

563 simply reflect the abundance of reduced energy sources such as methane, carbon

564 monoxide, and hydrogen on the early Earth (Zerkle et al., 2005). Because higher Co

565 availability is linked to periods in Earth's history when the oceans were anoxic, had on

566 average lower Co burial rates, higher Co mobility, and probably longer Co residence

567 times, environmental availability and catalytic suitability may both be reflected in the

568 utilization of Co in organisms or proteins that evolved early. 
569 Consistent with a greater utilization of Co by early organisms, bacteria and archaea

570 have a greater number of genes that encode for Co-binding proteins (Zhang and

571 Gladyshev, 2010), and their genomes encode a larger proportion of Co-binding proteins

572 than eukarya (Dupont et al., 2006). In contrast, a lack of encoded Co-binding proteins in

573 eukarya should indicate evolution predominantly after $1.8 \mathrm{Ga}$. This is broadly consistent

574 with initial diversification of eukaryotes in the middle to late Proterozoic (Knoll et al.,

575 2007). The persistence of the cobalamin-requiring gene metH in eukaryotic

576 phytoplankton, involved in biosynthesis of the essential amino acid methionine,

577 suggests that lower marine Co concentrations were not a sufficient selection pressure to

578 drive loss of the metH gene in favor of a cobalamin-independent but less efficient gene

579 (Bertrand et al., 2013), or that key Co-binding proteins were maintained and few new

580 Co-binding proteins were acquired during genome expansion. Alternately, the

581 persistence of $\mathrm{metH}$ in eukaryotic phytoplankton may reflect a later acquisition (Croft et

582 al., 2005), and it often occurs in eukaryotic phytoplankton that already contained the

583 cobalamin-independent gene (Helliwell et al., 2011). Thus, eukaryotic metH persistence

584 may be related to its efficiency rather than Co availability.

585 Enzymes that directly bind Co rather than cobalamin also offer insight into how metal

586 availability regulates enzyme utilization. Both diatoms and eukaryotic algae can

587 substitute $\mathrm{Co}$ (or $\mathrm{Cd}$ ) for $\mathrm{Zn}$ in the carbonic anhydrase enzyme that interconverts $\mathrm{CO}_{2}$

588 and bicarbonate when $\mathrm{Zn}$ concentrations are limiting (Morel et al., 1994; Saito and

589 Goepfert, 2008). Such substitution may be a strategy for coastal algae to deal with

590 intense metal drawdown during algal blooms (Saito and Goepfert, 2008), but also

591 indicates that expression of metal-binding proteins encoded at the genomic level are 
592 affected by temporally and spatially variable metal concentrations. The trends in Co

593 sedimentary records presented here reflect geological control over element delivery and

594 burial; short-term and spatial variability will therefore not be resolvable with our dataset.

595 Furthermore, the amount of metal-binding protein expressed (i.e. the metallome) should 596 fluctuate with physical and chemical conditions and the physiological state of the cell

597 (Bertrand et al., 2013; Saito et al., 2011). Proteomic records are therefore an important 598 complement to the genome in understanding why utilization of metal-binding proteins 599 persist, are lost or acquired as metal concentrations change.

600 Finally, although genomic utilization may reflect availability of metals during 601 evolution, it can also indicate later adaptations to changing metal abundances. For 602 instance marine cyanobacteria have an absolute requirement for Co that cannot be met 603 by other metals (Saito et al., 2002; Sunda and Huntsman, 1995), which again may 604 reflect evolution in largely anoxic or sulfidic oceans with greater Co availability (Saito et 605 al., 2003), yet thrive in the oxic oceans where Co concentrations are often less than 40 606 pM. Cobalt utilization may have persisted in cyanobacteria as Co availability declined 607 due to the acquisition of Co-binding ligands (Saito and Moffett, 2001; Saito et al., 2005).

608 The hypothesis that availability dictates utilization implies that the earliest life lacked 609 strategies for acquisition of metals (Nisbet and Fowler, 1996). However, it is clear that

610 modern organisms possess strategies to deal with limitation. Thus, the evolutionary

611 history of metal-acquisition genes may be an important consideration when comparing

612 metal availability to biological utilization, and many of these proteins are still being 613 identified (Zhang and Gladyshev, 2010). 


\section{6. Conclusions}

616 Trace elements are proxies for tracking marine redox evolution, but most studies

617 have focused on metals that partition strongly into anoxic or sulfidic sediments (e.g.,

$618 \mathrm{Mo}$ ). For Co, and Fe and Mn, which have short residence times in the modern ocean,

619 marine concentrations respond dynamically to changes in delivery and removal. High

620 seawater Co concentrations from $\sim 2.8-1.84 \mathrm{Ga}$, recorded by IF and authigenic pyrites,

621 resulted from widespread anoxia and enhanced hydrothermal activity and are probably

622 linked to Fe fluxes that resulted in the deposition of IF. The marine Co reservoir

623 decreased after $\sim 1.84 \mathrm{Ga}$ due to waning hydrothermal Co delivery. The expansion of

624 euxinic sediments at the expense of anoxic sediments, which are a negligible sink for

625 Co, may have also contributed to the Middle Proterozoic Co reservoir decrease.

626 Variability of Phanerozoic IF and euxinic shale Co concentrations are linked to localized

627 hydrothermal activity and/or transient anoxic conditions, and as such obscure any global

628 changes in the marine Co reservoir associated with deep-water oxidation. Our study of

629 the concentrations of Co in marine sediments through time reveals a more nuanced

630 view of the marine Co reservoir through Earth's history than is possible with theoretical

631 models based on thermodynamic equilibrium (e.g. Saito et al., 2003). This emerging

632 view of the evolution of the marine Co reservoir through time provides a framework for

633 interpreting Co availability influenced the acquisition and utilization of Co in biology.

634

635 Acknowledgements EDS acknowledges support of the National Science Foundation

636 (NSF) IRFPand a Deutsche Forschungsgemeinschaft grant. NJP acknowledges support

637 of the National Science Foundation EAR-PF and NSF ELT program. SVL gratefully 
638 acknowledges postdoctoral fellowship support from NSERC and LabexMER. Discovery 639 Grants and CGS-M from NSERC supported KOK, AB, and LJR, respectively. OR 640 received support from Europole Mer and IFREMER. SJM was supported by the NASA 641 Exobiology Program, NASA's Astrobiology Institute Fund for International Cooperation, 642 the University of Colorado Center for Astrobiology, J.W. Fulbright Foundation, University 643 of Colorado's Office of the Vice Chancellor for Research, and a sabbatical stay at the

644 Centre de Recherches Pétrographiques et Géochimiques (CRPG-Nancy). This 645 manuscript benefitted from helpful discussions with Martin Wille.

646 


\section{REFERENCES}

648 Algeo, T.J., Maynard, J.B., 2004. Trace-element behavior and redox facies in core 649 shales of Upper Pennsylvanian Kansas-type cyclothems. Chemical Geology 206, 289650318.

651 Anbar, A.D., 2008. Elements and Evolution. Science 322, 1481-1483.

652 Arndt, N.T., 1983. Role of a thin, komatiite-rich oceanic crust in the Archean plate653 tectonic process. Geology 11, 372-375.

654 Banerjee, R., Ragsdale, S.W., 2003. The many faces of Vitamin B12: catalysis by 655 cobalamin-dependent enzymes. Annual Review of Biochemistry 72, 209-247.

656 Barley, M.E., Bekker, A., Krapež, B., 2005. Late Archean to Early Paleoproterozoic 657 global tectonics, environmental change and the rise of atmospheric oxygen. Earth and 658 Planetary Science Letters 238, 156-171.

659 Barley, M.E., Pickard, A.L., Sylvester, P.J., 1997. Emplacement of a large igneous 660 province as a possible cause of banded iron formation 2.45 billion years ago. Nature $661385,55-58$.

662 Bau, M., Moeller, P., 1993. Rare earth element systematics of the chemically 663 precipitated component in Early Precambrian iron formations and the evolution of the 664 terrestrial atmosphere-hydrosphere-lithosphere system. Geochimica et Cosmochimica 665 Acta 57, 2239-2249.

666 Beak, D.G., Kirby, J.K., Hettiarachchi, G.M., Wendling, L.A., McLaughlin, M.J., 667 Khatiwada, R., 2011. Cobalt Distribution and Speciation: Effect of Aging, Intermittent 668 Submergence, In Situ Rice Roots. Journal of Environmental Quality 40, 679-695.

669 Bekker, A., Slack, J.F., Planavsky, N., Krapez, B., Hofmann, A., Konhauser, K.O., 670 Rouxel, O.J., 2010. Iron Formation: The Sedimentary Product of a Complex Interplay 671 among Mantle, Tectonic, Oceanic, and Biospheric Processes. Economic Geology 105, 672 467-508.

673 Bertrand, E.M., Moran, D.M., Mcllvin, M.R., Hoffman, J.M., Allen, A.E., Saito, M.A., 674 2013. Methionine synthase interreplacement in diatom cultures and communities: 675 Implications for the persistence of B12 use by eukaryotic phytoplankton. Limnol. 676 Oceanogr. 58, 1431-1450.

677 Broecker, W.S., 1971. A kinetic model for the chemical composition of sea water. 678 Quaternary Research 1, 188-207.

679 Broecker, W.S., Peng, T.-H., 1982. Tracers in the Sea. Lamont-Doherty Geological 680 Observatory, Columbia University, Palisades, New York. 
681 Brumsack, H.-J., 1989. Geochemistry of recent TOC-rich sediments from the Gulf of 682 California and the Black Sea. Geologische Rundschau 78, 851-882.

683 Brumsack, H.-J., 2006. The trace metal content of recent organic carbon-rich 684 sediments: Implications for Cretaceous black shale formation. Palaeogeography, 685 Palaeoclimatology, Palaeoecology 232, 344-361.

686 Canfield, D.E., Raiswell, R., Bottrell, S., 1992. The reactivity of sedimentary iron 687 minerals toward sulfide. American Journal of Science 292, 659-683.

688 Carr, M.H., Turekian, K.K., 1961. The geochemistry of cobalt. Geochimica et 689 Cosmochimica Acta 23, 9-60.

690 Condie, K.C., 1993. Chemical composition and evolution of the upper continental crust: 691 Contrasting results from surface samples and shales. Chemical Geology 104, 1-37.

692 Croft, M.T., Lawrence, A.D., Raux-Deery, E., Warren, M.J., Smith, A.G., 2005. Algae 693 acquire vitamin B12 through a symbiotic relationship with bacteria. Nature 438, 90-93.

694 Daskalakis, K.D., Helz, G.R., 1992. Solubility of CdS (Greenockite) in sulfidic waters at 695 25C. Environmental Science \& Technology 26, 2462-2468.

696 David, L.A., Alm, E.J., 2011. Rapid evolutionary innovation during an Archaean genetic 697 expansion. Nature 469, 93-96.

698 Derry, L.A., Jacobsen, S.B., 1988. The Nd and $\mathrm{Sr}$ isotopic evolution of Proterozoic 699 seawater. Geophysical Research Letters 15, 397-400.

700 Douglas, G.B., Adeney, J.A., 2000. Diagenetic cycling of trace elements in the bottom 701 sediments of the Swan River Estuary, Western Australia. Applied Geochemistry 15, 702 551-566.

703 Douville, E., Charlou, J.L., Oelkers, E.H., Bienvenu, P., Jove Colon, C.F., Donval, J.P., 704 Fouquet, Y., Prieur, D., Appriou, P., 2002. The rainbow vent fluids (36'14'N, MAR): the 705 influence of ultramafic rocks and phase separation on trace metal content in Mid706 Atlantic Ridge hydrothermal fluids. Chemical Geology 184, 37-48.

707 Dryssen, D., Kremling, K., 1990. Increasing hydrogen sulfide concentration and trace 708 metal behavior in the anoxic Baltic waters. Marine Chemistry 30, 193-204.

709 Dupont, C.L., Yang, S., Palenik, B., Bourne, P.E., 2006. Modern proteomes contain 710 putative imprints of ancient shifts in trace metal geochemistry. Proceedings of the 711 National Academy of Sciences 103, 17822-17827.

712 Dzombak, D.A., Morel, F.M.M., 1990. Surface Complexation Modeling: Hydrous Ferric 713 Oxide. John Wiley \& Sons, Inc. 
714 Elderfield, H., Schultz, A., 1996. Mid-ocean ridge hydrothermal fluxes and the chemical

715 composition of the ocean. Annual Review of Earth and Planetary Sciences 24, 191-224.

716 Fraústo da Silva, J.J.R., Williams, R.J.P., 2001. The biological chemistry of the 717 elements, 2nd

718 ed. Oxford University Press, New York.

719 Froelich, P.N., Klinkhammer, G.P., Bender, M.L., Luedtke, N.A., Heath, G.R., Cullen, D., 720 Dauphin, P., Hammond, D., Hartman, B., Maynard, V., 1979. Early oxidation of organic 721 matter in pelagic sediments of the eastern equatorial Atlantic: suboxic diagenesis. 722 Geochimica et Cosmochimica Acta 43, 1075-1090.

723 Gaillardet, J., Viers, J., Dupre, B., 2003. 5.09 Trace elements in river waters, in: Drever, 724 J.I. (Ed.), Surface and Ground Water, Weathering, and Soils. Elsevier, pp. 225-272.

725 German, C.R., Campbell, A.C., Edmond, J.M., 1991. Hydrothermal scavenging at the 726 Mid-Atlantic Ridge: Modification of trace element dissolved fluxes. Earth and Planetary 727 Science Letters 107, 101-114.

728 Glassley, W.E., Piper, D.Z., 1978. Cobalt and scandium partitioning versus iron content 729 for crystalline phases in ultramafic nodules. Earth and Planetary Science Letters 39, 730 173-178.

731 Helliwell, K.E., Wheeler, G.L., Leptos, K.C., Goldstein, R.E., Smith, A.G., 2011. Insights 732 into the Evolution of Vitamin B12 Auxotrophy from Sequenced Algal Genomes. 733 Molecular Biology and Evolution 28, 2921-2933.

734 Helz, G.R., Bura-Nakić, E., Mikac, N., Ciglenečki, I., 2011. New model for molybdenum 735 behavior in euxinic waters. Chemical Geology 284, 323-332.

736 Hetzel, A., Böttcher, M.E., Wortmann, U.G., Brumsack, H.-J.r., 2009. Paleo-redox 737 conditions during OAE 2 reflected in Demerara Rise sediment geochemistry (ODP Leg 738 207). Palaeogeography, Palaeoclimatology, Palaeoecology 273, 302-328.

739 Ho, T.-Y., Quigg, A., Finkel, Z.V., Milligan, A.J., Wyman, K., Falkowski, P.G., Morel, 740 F.M.M., 2003. The elemental composition of some marine phytoplankton. Journal of 741 Phycology 39, 1145-1159.

742 Hrishceva, E., Scott, S.D., 2007. Geochemistry and morphology of metalliferous 743 sediments and oxyhydroxides from the Endeavour segment, Juan de Fuca Ridge. 744 Geochimica et Cosmochimica Acta 71, 3476-3497.

745 Huerta-Diaz, M.A., Morse, J.W., 1992. Pyritization of trace metals in anoxic marine 746 sediments. Geochimica et Cosmochimica Acta 56, 2681-2702.

747 Isley, A.E., 1995. Hydrothermal plumes and the delivery of iron to Banded Iron 748 Formations. Journal of Geology 103, 169-185. 
749 Kamber, B.S., 2010. Archean mafic-ultramafic volcanic landmasses and their effect on 750 ocean-atmosphere chemistry. Chemical Geology 274, $19-28$.

751 Kamber, B.S., Greig, A., Collerson, K.D., 2005. A new estimate for the composition of 752 weathered young upper continental crust from alluvial sediments, Queensland, 753 Australia. Geochimica et Cosmochimica Acta 69, 1041-1058.

754 Knoll, A.H., Summons, R.E., Waldbauer, J.R., Zumberge, J.E., 2007. The geological 755 succession of primary producers in the oceans., in: Falkowski, P.G., Knoll, A.H. (Eds.), 756 Evolution of Primary Producers in the Sea. Elsevier, Boston, pp. 133-163.

757 Konhauser, K.O., Lalonde, S.V., Amskold, L., Holland, H.D., 2007. Was There Really an 758 Archean Phosphate Crisis? Science 315, 1234.

759 Konhauser, K.O., Lalonde, S.V., Planavsky, N.J., Pecoits, E., Lyons, T.W., Mojzsis, 760 S.J., Rouxel, O.J., Barley, M.E., Rosiere, C., Fralick, P.W., Kump, L.R., Bekker, A., 761 2011. Aerobic bacterial pyrite oxidation and acid rock drainage during the Great 762 Oxidation Event. Nature 478, 369-373.

763 Konhauser, K.O., Newman, D.K., Kappler, A., 2005. The potential significance of 764 microbial $\mathrm{Fe}(\mathrm{III})$ reduction during deposition of Precambrian banded iron formations. 765 Geobiology 3, 167-177.

766 Konhauser, K.O., Pecoits, E., Lalonde, S.V., Papineau, D., Nisbet, E.G., Barley, M.E., 767 Arndt, N.T., Zahnle, K., Kamber, B.S., 2009. Oceanic nickel depletion and a 768 methanogen famine before the Great Oxidation Event. Nature 458, 750-753.

769 Koschinsky, A., Hein, J.R., 2003. Uptake of elements from seawater by ferromanganese 770 crusts: solid-phase associations and seawater speciation. Marine Geology 198, 331771351.

772 Krauskopf, K.B., 1956. Factors controlling the concentrations of thirteen rare metals in 773 sea-water. Geochimica et Cosmochimica Acta 9, 1-32.

774 Kremling, K., 1983. The behavior of $\mathrm{Zn}, \mathrm{Cd}, \mathrm{Cu}, \mathrm{Ni}, \mathrm{Co}, \mathrm{Fe}$, and $\mathrm{Mn}$ in anoxic baltic 775 waters. Marine Chemistry 13, 87-108.

776 Krishnaswami, S., 1976. Authigenic transition elements in Pacific pelagic clays. 777 Geochimica et Cosmochimica Acta 40, 425-434.

778 Limpert, E., Stahel, W.A., Abbt, M., 2001. Log-normal Distributions across the Sciences: 779 Keys and Clues. BioScience 51, 341-352.

780 Lyons, T.W., Werne, J.P., Hollander, D.J., Murray, R.W., 2003. Contrasting sulfur 781 geochemistry and Fe/Al and Mo/Al ratios across the last oxic-to-anoxic transition in the 782 Cariaco Basin, Venezuela. Chemical Geology 195, 131-157. 
783 Manceau, A., Drits, V.A., Silvester, E., Bartoli, C., Lanson, B., 1997. Structural 784 mechanism of $\mathrm{Co2}+$ oxidation by the phyllomanganate buserite. American Mineralogist 785 82, 1150-1175.

786 Metz, S., Trefry, J.H., 2000. Chemical and mineralogical influences on concentrations of 787 trace metals in hydrothermal fluids. Geochimica et Cosmochimica Acta 64, 2267-2279.

788 Moffett, J.W., Ho, J., 1996. Oxidation of cobalt and manganese in seawater via a 789 common microbially catalyzed pathway. Geochimica et Cosmochimica Acta 60, 34153424.

791 Morel, F.M.M., Reinfelder, J.R., Roberts, S.B., Chamberlain, C.P., Lee, J.G., Yee, D., 792 1994. Zinc and carbon co-limitation of marine phytoplankton. Nature 369, 740-742.

793 Morse, J.W., Arakaki, T., 1993. Adsorption and coprecipitation of divalent metals with 794 mackinawite (FeS). Geochimica et Cosmochimica Acta 57, 3635-3640.

795 Morse, J.W., Luther III, G.W., 1999. Chemical influences on trace metal-sulfide 796 interactions in anoxic sediments. Geochimica et Cosmochimica Acta 63, 3373-3378.

797 Murray, J.W., Dillard, J.G., 1979. The oxidation of cobalt(II) adsorbed on manganese 798 dioxide. Geochimica et Cosmochimica Acta 43, 781-787.

799 Murray, K.J., Webb, S.M., Bargar, J.R., Tebo, B.M., 2007. Indirect Oxidation of Co(II) in 800 the Presence of the Marine Mn(II)-Oxidizing Bacterium Bacillus sp. Strain SG-1. Applied 801 and Environmental Microbiology 73, 6905-6909.

802 Musić, S., Gessner, M., Wolf, R.H.H., 1979. Sorption of small amounts of cobalt(II) on 803 iron(III) oxide. Microchimica Acta 71, 105-112.

804 Nisbet, E.G., Fowler, C.M.R., 1996. The hydrothermal imprint on life: did heat-shock 805 proteins, metalloproteins and photosynthesis begin around hydrothermal vents? 806 Geological Society, London, Special Publications 118, 239-251.

807 Noble, A.E., Lamborg, C.H., Ohnemus, D.C., Lam, P.J., Goepfert, T.J., Measures, C.I., 808 Frame, C.H., Casciotti, K.L., DiTullio, G.R., Jennings, J., Saito, M.A., 2012. Basin-scale 809 inputs of cobalt, iron, and manganese from the Benguela-Angola front to the South 810 Atlantic Ocean. Limnol. Oceanogr. 57, 989-1010.

811 Noble, A.E., Saito, M.A., Maiti, K., Benitez-Nelson, C.R., 2008. Cobalt, manganese, and 812 iron near the Hawaiian Islands: A potential concentrating mechanism for cobalt within a 813 cyclonic eddy and implications for the hybrid-type trace metals. Deep-Sea Research II 814 55, 1473-1490.

815 Orth, C.J., Attrep Jr, M., Quintana, L.R., Elder, W.P., Kauffman, E.G., Diner, R., Villamil, 816 T., 1993. Elemental abundance anomalies in the late Cenomanian extinction interval: a 817 search for the source(s). Earth and Planetary Science Letters 117, 189-204. 
818 Öztürk, M., 1995. Trends of trace metal ( $\mathrm{Mn}, \mathrm{Fe}, \mathrm{Co}, \mathrm{Ni}, \mathrm{Cu}, \mathrm{Zn}, \mathrm{Cd}$ and $\mathrm{Pb}$ ) 819 distributions at the oxic-anoxic interface in sulfidic water of the Drammensjord. Marine 820 Chemistry 48, 329-342.

821 Peng, P., Bleeker, W., Ernst, R.E., Söderlund, U., McNicoll, V., 2011. U-Pb baddeleyite 822 ages, distribution and geochemistry of 925\&\#xa0;Ma mafic dykes and 900\&\#xa0;Ma 823 sills in the North China craton: Evidence for a Neoproterozoic mantle plume. Lithos 127, 824 210-221.

825 Piper, D.Z., Dean, W.E., 2002. Trace element deposition in the Cariaco Basin, 826 Venezuala shelf, under sulfate-reducing conditions - a history of the local hydrography 827 and global climate, 20 ka to the present, USGS Professional Paper, p. 45 pp.

828 Planavsky, N., Bekker, A., Rouxel, O.J., Kamber, B., Hofmann, A., Knudsen, A., Lyons, 829 T.W., 2010a. Rare Earth Element and yttrium compositions of Archean and 830 Paleoproterozoic Fe formations revisited: New perspectives on the significance and 831 mechanisms of deposition. Geochimica et Cosmochimica Acta 74, 6387-6405.

832 Planavsky, N.J., McGoldrick, P., Scott, C.T., Li, C., Reinhard, C.T., Kelly, A.E., Chu, X., 833 Bekker, A., Love, G.D., Lyons, T.W., 2011. Widespread iron-rich conditions in the mid834 Proterozoic ocean. Nature 477, 448-451.

835 Planavsky, N.J., Rouxel, O.J., Bekker, A., Lalonde, S.V., Konhauser, K.O., Reinhard, 836 C.T., Lyons, T.W., 2010b. The evolution of the marine phosphate reservoir. Nature 467, 837 1088-1090.

838 Pons, M.L., Fujii, T., Rosing, M., Quitté, G., Télouk, P., Albarède, F., 2013. A Zn isotope 839

840 Poulton, S.W., Fralick, P.W., Canfield, D.E., 2004. The transition to a sulphidic ocean $841 \sim 1.84$ billion years ago. Nature 431, 173-177.

842 Rasmussen, B., Buick, R., 1999. Redox state of the Archean atmosphere: Evidence 843 from detrital heavy minerals in ca. 3250-2750 Ma sandstones from the Pilbara Craton, 844 Australia. Geology 27, 115-118.

845 Rasmussen, B., Fletcher, I.R., Bekker, A., Muhling, J.R., Gregory, C.J., Thorne, A.M., 846 2012. Deposition of 1.88-billion-year-old iron formations as a consequence of rapid 847 crustal growth. Nature 484, 498-501.

848 Reinhard, C.T., Planavsky, N.J., Robbins, L.J., Partin, C.A., Gill, B.C., Lalonde, S.V., 849 Bekker, A., Konhauser, K.O., Lyons, T.W., 2013. Proterozoic ocean redox and 850

851 Robbins, L.J., Lalonde, S.V., Saito, M.A., Planavsky, N.J., Mloszewska, A.M., Pecoits, 852 E., Scott, C., Dupont, C.L., Kappler, A., Konhauser, K.O., 2013. Authigenic iron oxide 853 proxies for marine zinc over geological time and implications for marine eukaryotic 854 metallome evolution. Geobiology 11, 295-306. 
855 Rouxel, O.J., Bekker, A., Edwards, K.J., 2005. Iron Isotope Constraints on the Archean 856 and Paleoproterozoic Ocean Redox State. Science 307, 1088-1091.

857 Rouxel, O.J., Bekker, A., Edwards, K.J., 2006. Response to Comment on "Iron Isotope 858 Constraints on the Archean and Paleoproterozoic Ocean Redox State. Science 311.

859 Sahoo, S.K., Planavsky, N.J., Kendall, B., Wang, X., Shi, X., Scott, C., Anbar, A.D., 860 Lyons, T.W., Jiang, G., 2012. Ocean oxygenation in the wake of the Marinoan 861 glaciation. Nature 489, 546-549.

862 Saito, M.A., Bertrand, E.M., Dutkiewicz, S., Bulygin, V.V., Moran, D.M., Monteiro, F.M., 863 Follows, M.J., Valois, F.W., Waterbury, J.B., 2011. Iron conservation by reduction of 864 metalloenzyme inventories in the marine diazotroph Crocosphaera watsonii. 865 Proceedings of the National Academy of Sciences 108, 2184-2189.

866 Saito, M.A., Goepfer, T.J., Noble, A.E., Bertrand, E.M., Sedwick, P.N., DiTullio, G.R., 867 2010. A seasonal study of dissolved cobalt in the Ross Sea, Antarctica: micronutrient 868 behavior, absence of scavenging, and relationships with $\mathrm{Zn}, \mathrm{Cd}$, and P. Biogeosciences 869 7, 4059-4082.

870 Saito, M.A., Goepfert, T.J., 2008. Zinc-cobalt colimitation of Phaeocystis antarctica. 871 Limnol. Oceanogr. 53, 266-275.

872 Saito, M.A., Moffett, J.W., 2001. Complexation of cobalt by natural organic ligands in the 873 Sargasso Sea as determined by a new high-sensitivity electrochemical cobalt speciation 874 method suitable for open ocean work. Marine Chemistry 75, 49-68.

875 Saito, M.A., Moffett, J.W., 2002. Temporal and spatial variability of cobalt in the Atlantic 876 Ocean. Geochimica et Cosmochimica Acta 66, 1943-1953.

877 Saito, M.A., Moffett, J.W., Chisholm, S.W., Waterbury, J.B., 2002. Cobalt limitation and 878 uptake in Prochlorococcus. Limnology and Oceanography 47, 1629-1636.

879 Saito, M.A., Moffett, J. W. and G. R. DiTullio, 2004. Cobalt and nickel in the Peru 880 upwelling region: A major flux of labile cobalt utilized as a micronutrient. Global 881 Biogeochemical Cycles 18.

882 Saito, M.A., Noble, A.E., Tagliabue, A., Goepfert, T.J., Lamborg, C.H., Jenkins, W.J., 883 2013. Slow-spreading submarine ridges in the South Atlantic as a significant oceanic 884 iron source. Nature Geosci 6, 775-779.

885 Saito, M.A., Rocap, G., Moffett, J.W., 2005. Production of cobalt binding ligands in a 886 Synechococcus feature at the Costa Rica upwelling dome. Limnology and 887 Oceanography 50, 279-290.

888 Saito, M.A., Sigman, D.M., Morel, F.M.M., 2003. The bioinorganic chemistry of the 889 ancient ocean: the co-evolution of the cyanobacterial metal requirements and 
890 biogeochemical cycles at the Archean-Paleoproterozoic boundary? Inorganica Chimica 891 Acta 356, 308-318.

892 Sander, S.G., Koschinsky, A., 2011. Metal flux from hydrothermal vents increased by 893 organic complexation. Nature Geoscience 4, 145-150.

894 Scott, C., Lyons, T.W., 2012. Contrasting molybdenum cycling and isotopic properties in 895 euxinic versus non-euxinic sediments and sedimentary rocks: Refining the 896 paleoproxies. Chemical Geology 324-325, 19-27.

897 Scott, C., Lyons, T.W., Bekker, A., Shen, Y., Poulton, S.W., Chu, X., Anbar, A.D., 2008. 898 Tracing the stepwise oxygenation of the Proterozoic ocean. Nature 452, 456-459.

899 Scott, C., Planavsky, N.J., Dupont, C.L., Kendall, B., Gill, B.C., Robbins, L.J., Husband, 900 K.F., Arnold, G.L., Wing, B.A., Poulton, S.W., Bekker, A., Anbar, A.D., Konhauser, K.O., 901 Lyons, T.W., 2012. Bioavalability of zinc in marine systems through time. Nature 902 Geoscience 6, 125-128.

903 Shelley, R.U., Sedwick, P.N., Bibby, T.S., Cabedo-Sanz, P., Church, T.M., Johnson, 904 R.J., Macey, A.I., Marsay, C.M., Sholkovitz, E.R., Ussher, S.J., Worsfold, P.J., Lohan, 905 M.C., 2012. Controls on dissolved cobalt in surface waters of the Sargasso Sea: 906 Comparisons with iron and aluminum. Global Biogeochem. Cycles 26.

907 Snow, L.J., Duncan, R.A., Bralower, T.J., 2005. Trace element abundances in the Rock 908 Canyon Anticline, Pueblo, Colorado, marine sedimentary section and their relationship 909 to Caribbean plateau construction and oxygen anoxic event 2. Paleoceanography 20, 910 PA3005.

911 Stockdale, A., Davison, W., Zhang, H., Hamilton-Taylor, J., 2010. The association of 912 cobalt with iron and manganese (oxyhydr)oxides in marine sediment. Aquatic 913 Geochemistry 16, 575-585.

914 Stramma, L., Johnson, G.C., Sprintall, J., Mohrholz, V., 2008. Expanding Oxygen915 Minimum Zones in the Tropical Oceans. Science 320, 655-658.

916 Sunda, W.G., Huntsman, S.A., 1995. Cobalt and Zinc Interreplacement in Marine 917 Phytoplankton: Biological and Geochemical Implications. Limnology and Oceanography 918 40, 1404-1417.

919 Tagliabue, A., Bopp, L., Dutay, J.-C., Bowie, A.R., Chever, F., Jean-Baptiste, P., 920 Bucciarelli, E., Lannuzel, D., Remenyi, T., Sarthou, G., Aumont, O., Gehlen, M., 921 Jeandel, C., 2010. Hydrothermal contribution to the oceanic dissolved iron inventory. 922 Nature Geosci 3, 252-256.

923 Takahashi, Y., Manceau, A., Geoffroy, N., Marcus, M.A., Usui, A., 2007. Chemical and 924 structural control of the partitioning of $\mathrm{Co}, \mathrm{Ce}$, and $\mathrm{Pb}$ in marine ferromanganese oxides. 925 Geochimica et Cosmochimica Acta 71, 984-1008. 
926 Toner, B.M., Fakra, S.C., Manganini, S.J., Santelli, C.M., Marcus, M.A., Moffett, J.W., 927 Rouxel, O., German, C.R., Edwards, K.J., 2009. Preservation of iron(II) by carbon-rich 928 matrices in a hydrothermal plume. Nature Geosciences 2, 197-201.

929 Turgeon, S.C., Creaser, R.A., 2008. Cretaceous oceanic anoxic event 2 triggered by a 930 massive magmatic episode. Nature 454, 323-326.

931 Van der Weijden, C.H., 2002. Pitfalls of normalization of marine geochemical data using 932 a common divisor. Marine Geology 184, 167-187.

933 van der Weijden, C.H., Reichart, G.-J., van Os, B.J.H., 2006. Sedimentary trace 934 element records over the last $200 \mathrm{kyr}$ from within and below the northern Arabian Sea 935 oxygen minimum zone. Marine Geology 231, 69-88.

936 Veizer, J., Compston, W., Clauer, N., Schidlowski, M., 1983. 87Sr86Sr in Late 937 Proterozoic carbonates: evidence for a "mantle" event at $\sim 900 \mathrm{Ma}$ ago. Geochimica et 938 Cosmochimica Acta 47, 295-302.

939 Viollier, E., Jézéquel, D., Michard, G., Pèpe, M., Sarazin, G., Albéric, P., 1995. 940 Geochemical study of a crater lake (Pavin Lake, France): trace-element behaviour in 941 the monimolimnion. Chemical Geology 125, 61-72.

942 Wedephol, K.H., 1971. Environmental influences on the chemical composition of shales 943 and clays, in: Ahrens, L.H., Press, F., Runcorn, S.K., Urey, H.C. (Eds.), Physics and 944 Chemistry of the Earth. Pergamom Press, Oxford, United Kingdom, pp. 307-333.

945 Wheat, C.G., Jannasch, H.W., Kastner, M., Plant, J.N., DeCarlo, E.H., 2003. Seawater 946 transport and reaction in upper oceanic basaltic basement: chemical data from 947 continuous monitoring of sealed boreholes in a ridge flank environment. Earth and 948 Planetary Science Letters 216, 549-564.

949 Yee, N., Fein, J.B., 2003. Quantifying Metal Adsorption onto Bacteria Mixtures: A Test 950 and Application of the Surface Complexation Model. Geomicrobiology Journal 20, 43.

951 Yucel, M., Gartman, A., Chan, C.S., Luther, G.W., 2011. Hydrothermal vents as a 952 kinetically stable source of iron-sulphide-bearing nanoparticles to the ocean. Nature 953 Geoscience 4, 367-371.

954 Zerkle, A.L., House, C.H., Brantley, S.L., 2005. Biogeochemical signatures through time 955 as inferred from whole microbial genomes. American Journal of Science 305, 467-502.

956 Zhang, Y., Gladyshev, V.N., 2010. General Trends in Trace Element Utilization 957 Revealed by Comparative Genomic Analyses of $\mathrm{Co}, \mathrm{Cu}, \mathrm{Mo}, \mathrm{Ni}$, and Se. The Journal of 958 Biological Chemistry 285, 3393-3405.

959

960 


\section{Figures and Tables}

962 Fig. 1. a. Speciation diagram of $\mathrm{Co}$ (white) and $\mathrm{Fe}$ in varying $\mathrm{Eh}-\mathrm{pH}$ conditions. $\mathrm{Co}^{2+}$ is

963 stable under marine Eh and $\mathrm{pH}$ conditions (i.e. 7-8) inferred for the Precambrian ocean.

964 In the absence of carbonate, $\mathrm{Fe}^{2+}$ is soluble. b. Speciation diagram of Co (white) and

$965 \mathrm{Mn}$, showing the similar redox potential for $\mathrm{Mn}(\mathrm{II})$ and $\mathrm{Co}(\mathrm{II})$ oxidation, which are both

966 higher than that of $\mathrm{Fe}(\mathrm{II})$ oxidation.

967 Fig. 2. Co-precipitation of Co with Fe (oxyhydr)oxides can be inferred based on a 968 correlation coefficient of 0.763 from previously published data from hydrothermal 969 sediments at the Endeavor Segment, Juan de Fuca Ridge (Hrishceva and Scott, 2007).

970 Fig. 3. Sorption of $\mathrm{Co}^{2+}$ to strong $>(\mathrm{s})$ and weak $>(\mathrm{w})$ surface sites on ferrihydrite in

971 seawater when a. no organic Co-ligands are present, b. modern (40 pM) concentrations

972 of organic ligands (dashed line) are present, and c. for an extreme case of $400 \mathrm{pM}$ of

973 organic ligands.

974 Fig. 4. The Co/Ti of IF (symbols) and of evolving continental crust (black line; Condie,

975 1993). Data points are from bulk (squares) and laser-ablation (circles) analyses of

976 Precambrian Superior-type IF (red) and Algoma-type IF (black). Also included are

977 Phanerozoic shallow-marine ironstones (blue) and hydrothermal and exhalative

978 deposits (green). Data points with $>0.5 \mathrm{wt} \% \mathrm{Mn}$ have been excluded from this 979 compilation.

980 Fig. 5. Cobalt concentrations in pyrite (circles) from modern (open) and ancient (filled)

981 euxinic shales, and bulk euxinic shales (squares). For reference, the crustal evolution

982 trend (solid line) is included, based on the Restoration Model of Condie (1993). Modern 
983 pyrite Co concentrations from coastal sediments reflect high concentrations of trace

984 metals delivered from rivers and petroleum reservoirs (Huerta-Diaz and Morse, 1992).

985

\section{Table 1. Modern Cobalt Budget}

Sources

Riverine Flux

$5.5 \times 10^{12}$

$\mathrm{g} \mathrm{kyr}^{-1}$

Hydrothermal Flux

$1.3 \times 10^{11}$

$\mathrm{g} \mathrm{kyr}^{-1}$

Oceanic Reservoir

Mass

Residence Time

$1.6 \times 10^{12}$

0.28

g

kyr

\section{Sinks}

Oxic MAR

2.3-5

$\mu \mathrm{g} \mathrm{Co} \mathrm{cm}^{-2} \mathrm{kyr}^{-1}$

Euxinic MAR

5

$\mu \mathrm{g} \mathrm{Co} \mathrm{cm}^{-2} \mathrm{kyr}^{-1}$ 
Table 2. Statistical differences between Cobalt concentrations in sediments by age bin.

Iron Formations

\begin{tabular}{lccc} 
Age Bin & Mean Co/Al $\left(\mu \mathrm{g} \mathrm{g}^{-1}\right)$ & */ SD & $p$-value \\
\hline$\geq 2.80 \mathrm{Ga}$ & 79.85 & 1.72 & \\
2.75 to $1.88 \mathrm{Ga}$ & 150.57 & 2.67 & $<0.0001$ \\
$\leq 1.72 \mathrm{Ga}$ & 62.25 & 1.84 & $<0.0001$ \\
\hline
\end{tabular}

Euxinic Shale Pyrite

\begin{tabular}{lccc} 
Age Bin & Mean Co $(\mathrm{ppm})$ & */ SD & $p$-value \\
\hline 2.80 to $1.84 \mathrm{Ga}$ & 7.34 & 1.77 & \\
1.80 to $0.30 \mathrm{Ga}$ & 3.87 & 1.96 & $<0.0001$ \\
\hline
\end{tabular}

Euxinic Shale

\begin{tabular}{lccc} 
Age Bin & Mean Co/Ti $\left(\mu \mathrm{g} \mathrm{g}^{-1}\right)$ & $* / \mathrm{SD}$ & $p$-value \\
\hline$\geq 0.695 \mathrm{Ga}$ & 11.51 & 1.73 & \\
$\leq 0.531 \mathrm{Ga}$ & 9.33 & 1.97 & 0.0842
\end{tabular}

${ }^{*} p$-values refer to comparison between the age bin indicated and the preceding age bin.

\section{Supplementary Figures and Tables}

998 Supplementary Table 1. Co, Ti, Fe, and Mn concentrations and the source of the data

999 for the iron-formation samples used in this study.

1000 Supplementary Table 2. Co concentrations and the source of the data for pyrite and 1001 bulk shale analyses used in this study.

1002 Supplementary references 
Click here to download high resolution image

Figure 1
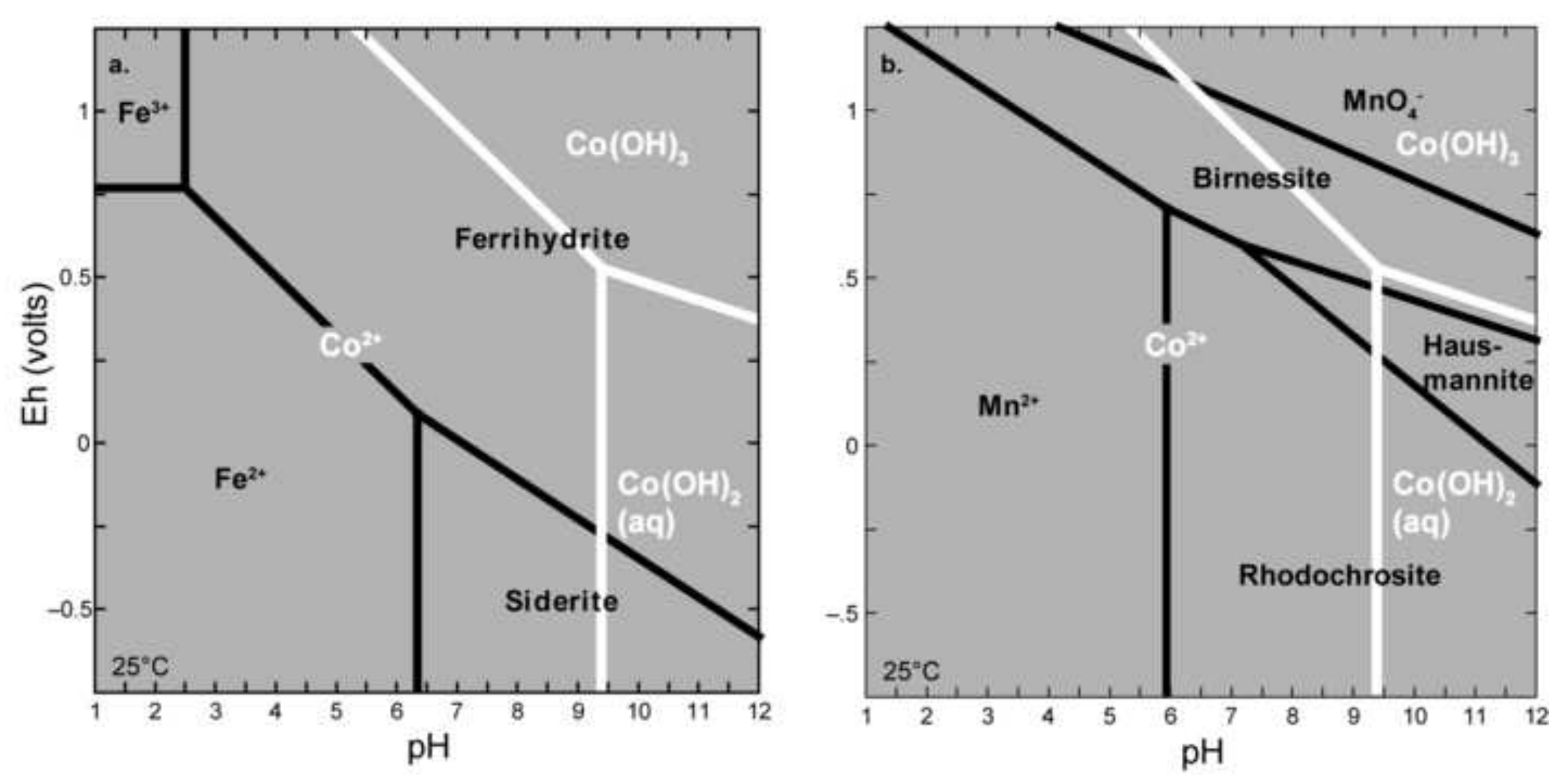
Figure 2

Click here to download high resolution image

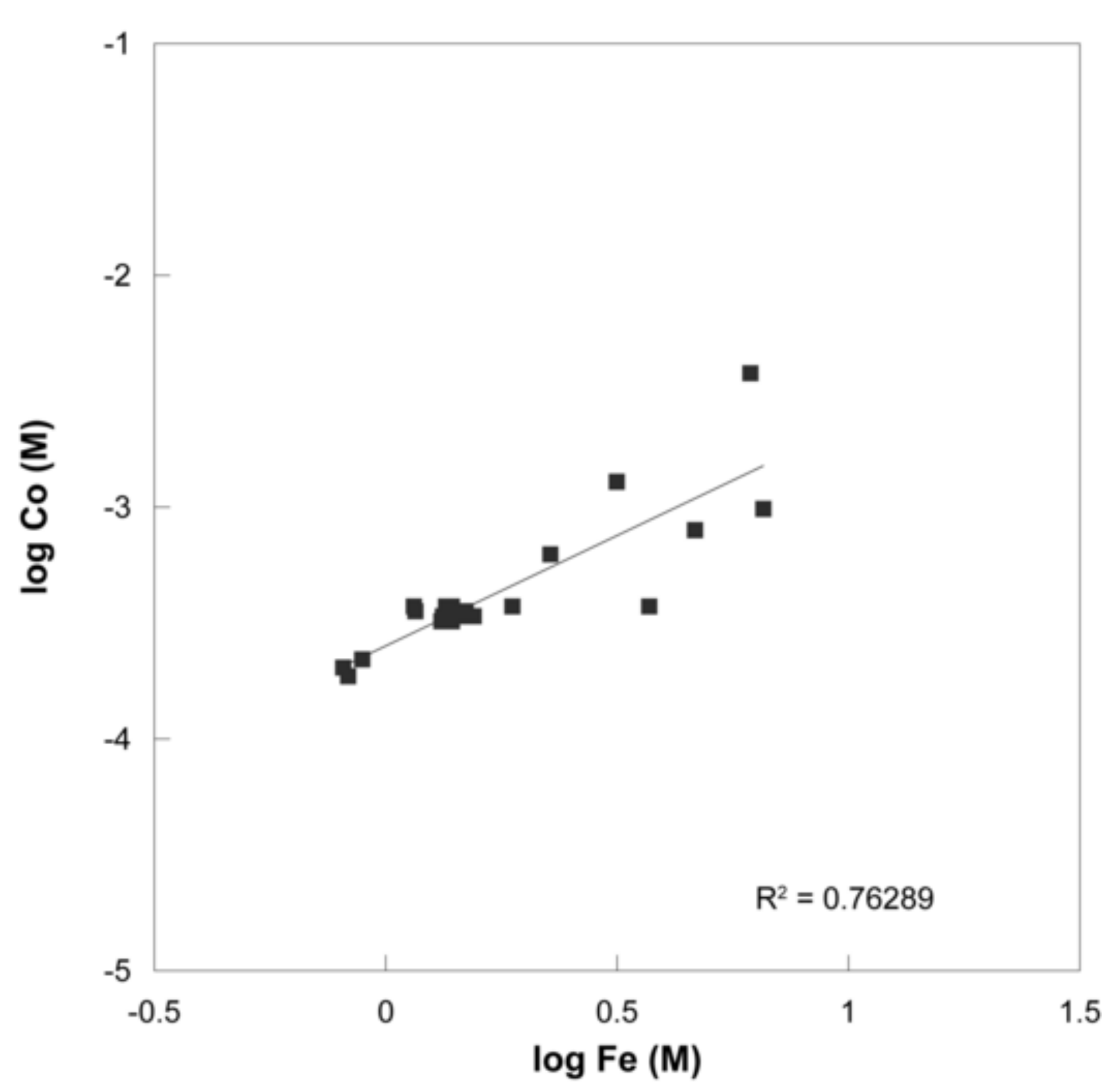

\section{Figure 2.}


Figure 3

Click here to download high resolution image

Figure 3
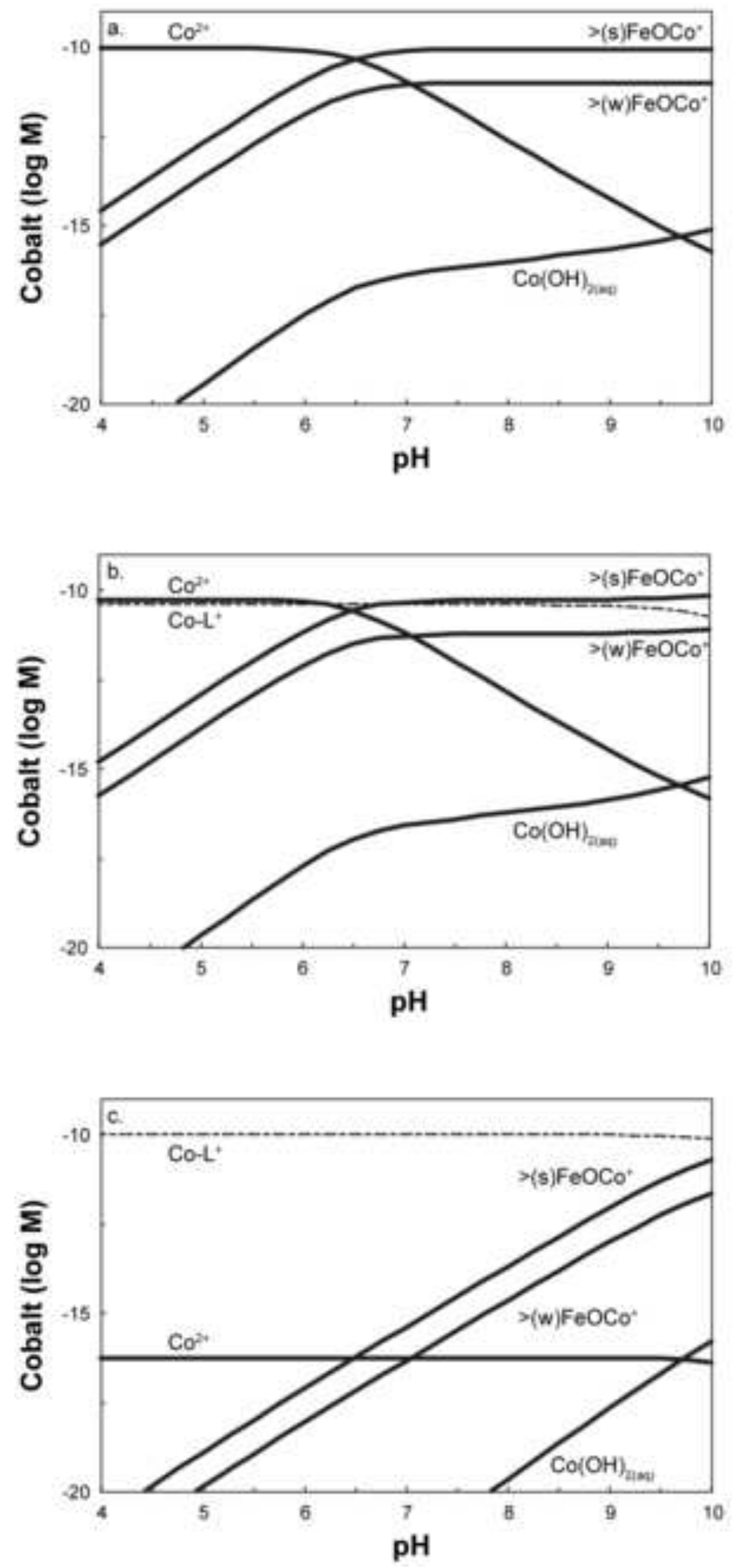
Figure 4.

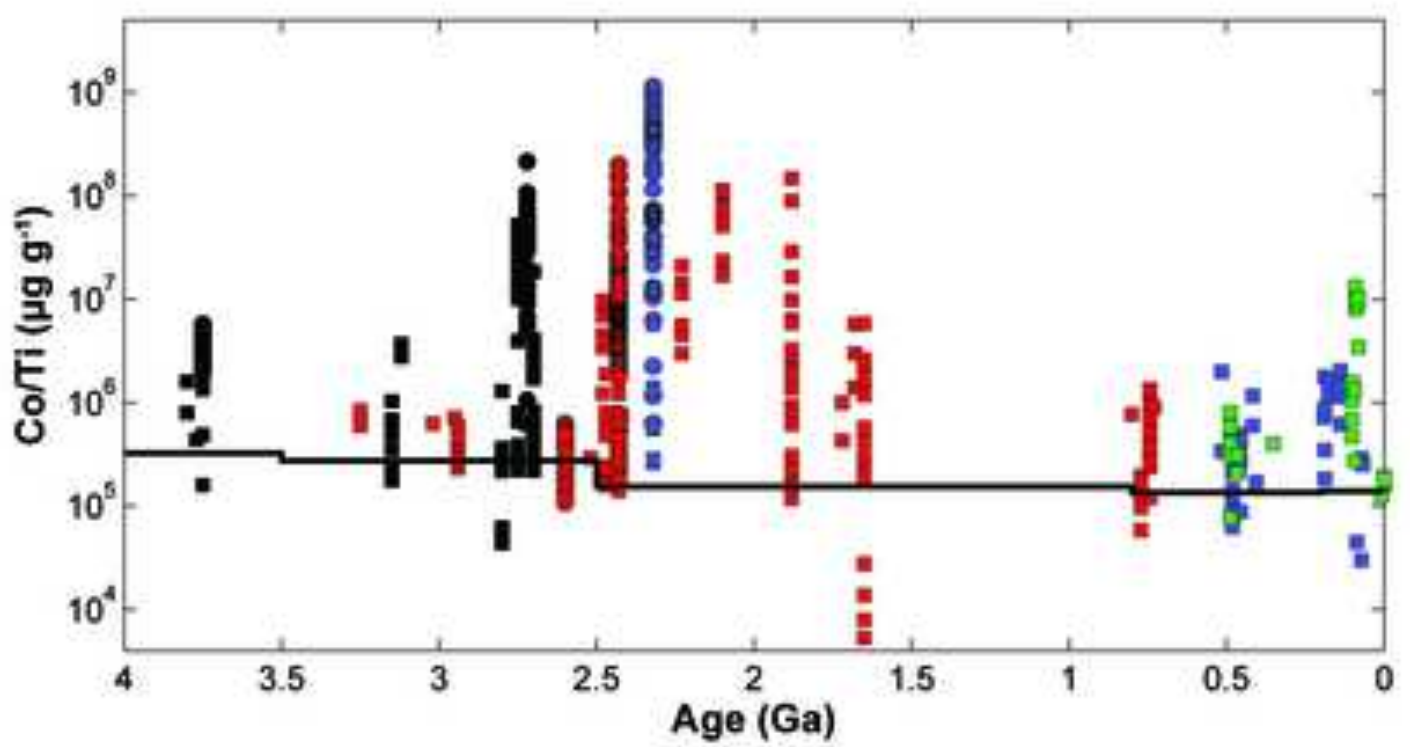


Figure 5.

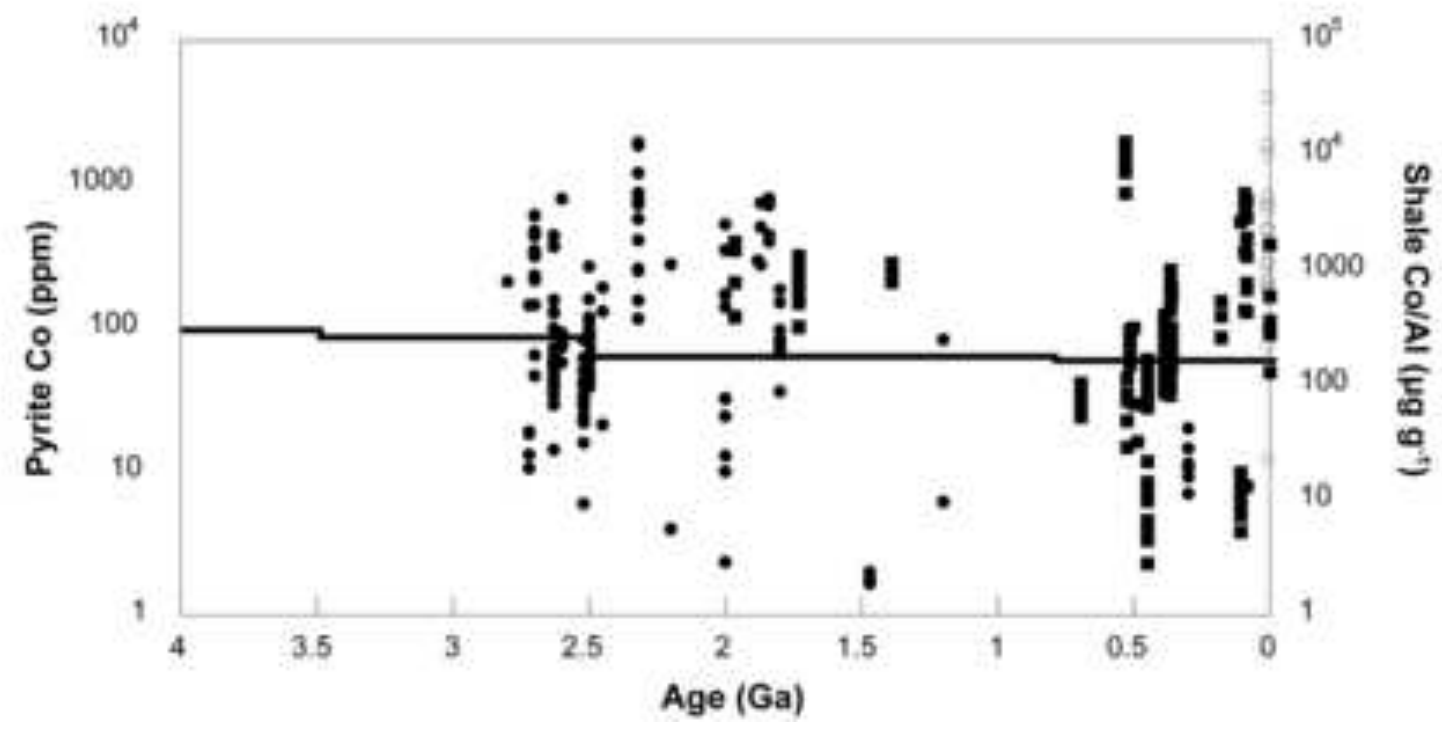


Click here to download Table: Cobalt_tables_v2.xIsx

Table 1. Modern Cobalt Budget

Sources

Riverine Flux

$5.5 \times 10^{12}$

Hydrothermal Flux

$1.3 \times 10^{11}$

$\mathrm{g} \mathrm{kyr}^{-1}$

$\mathrm{g} \mathrm{kyr}^{-1}$

Oceanic Reservoir Mass

Residence Time

$1.6 \times 10^{12}$

0.28

g

kyr

Sinks

Oxic MAR

2.3-5

$\mu \mathrm{g} \mathrm{Co} \mathrm{cm}^{-2} \mathrm{kyr}^{-1}$

Euxinic MAR

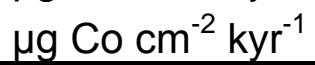




\author{
Click here to download Supplementary material for on-line publication only: Supplementary_Table1_references.doc Supplementary references
Click here to download Sup 